\title{
DOES THE RIGHT TO CARRY CONCEALED HANDGUNS DETER COUNTABLE CRIMES? ONLY A COUNT ANALYSIS CAN SAY*
}

\author{
FLORENZ PLASSMANN \\ State University of New \\ York at Binghamton
}

\author{
and \\ T. NICOLAUS TIDEMAN \\ Virginia Polytechnic \\ Institute and State \\ University
}

\begin{abstract}
An analysis of the effects of right-to-carry laws on crime requires particular distributional and structural considerations. First, because of the count nature of crime data and the low number of expected instances per observation in the most appropriate data, least-squares methods yield unreliable estimates. Second, use of a single dummy variable as a measure of the nationwide effect of right-to-carry laws is likely to introduce geographical and intertemporal aggregation biases into the analysis. In this paper, we use a generalized Poisson process to examine the geographical and dynamic effects of right-to-carry laws on reported homicides, rapes, and robberies. We find that the effects of such laws vary across crime categories, U.S. states, and time and that such laws appear to have statistically significant deterrent effects on the numbers of reported murders, rapes, and robberies.
\end{abstract}

\section{INTRODUCTION}

\section{A}

THEORETICAL economic model of crime gives an ambiguous answer to the question of the expected effect of the right to carry concealed handguns on crime. On the one hand, making it easier to carry a gun lowers the cost of defending potential victims against attack, which implies that the expected cost of committing a crime rises for the offender because of the increased probability of encountering an armed victim or bystander. On the other hand, the presence of a gun might transform a game or an otherwise nonviolent dispute into a situation with a deadly ending, and a right to carry guns also reduces the risk to an offender of preparing to commit crimes that are facilitated by carrying guns. As in all economic scenarios in which the demand and supply schedules shift downward, the direction of change in equilibrium depends on the magnitudes of the changes in both schedules. An empirical

* We wish to thank John Lott for providing us with the data for our analysis.

[Journal of Law and Economics, vol. XLIV (October 2001)]

(C) 2001 by The University of Chicago. All rights reserved. 0022-2186/2001/4402-0019\$01.50 
analysis is needed to determine the actual directions of the effects of the right to carry concealed handguns on crime. ${ }^{1}$

John Lott and David Mustard ${ }^{2}$ argue that such an empirical analysis will be unreliable if it is undertaken on the state level, because counties within a state are too heterogeneous to warrant the aggregation of county-level data to the state level. Their least-squares county-level analysis suggests that the adoption of right-to-carry laws has led to statistically significant reductions in most crime rates. With respect to murder, however, William Bartley and Mark Cohen ${ }^{3}$ show that Lott and Mustard's estimates are a result of their decision to include the arrest rate, a proxy for police efficiency, as an independent variable.

The arrest rate is calculated as the ratio of arrests to the number of crimes, and it is not defined when the number of crimes is zero in a county-year. This leads Lott and Mustard to exclude all county-years without any murders, or more than 40 percent of all observations. Once the arrest rate is excluded and all available observations are used, a least-squares analysis of murder no longer yields a statistically significant estimate. Rape and robbery are two other crimes that have zero reported occurrences in a large proportion of counties each year, but exclusion of the arrest rate and use of all available observations does not change the statistical significance of the least-squares estimates for these crimes.

Lott and Mustard, ${ }^{4}$ as well as Dan Black and Daniel Nagin ${ }^{5}$ and Bartley and Cohen, ${ }^{6}$ use weighted least squares to explain the impact of right-tocarry laws on county crime rates. These analyses ignore the fact that crime rates cannot fall below zero. We argue that this practice makes their results unreliable for crimes with low occurrence rates, and we suggest that a count analysis is more appropriate. While the standard approach to estimating such count-data models is to undertake a maximum-likelihood analysis using the Poisson or the negative binomial distribution, we find that a Markov chain Monte Carlo analysis of a Poisson-lognormal model is easier to implement and yields more precise estimates for the crime data.

Black and Nagin ${ }^{7}$ suggest that a model that tries to capture the effect of right-to-carry laws on crime with a single dummy variable makes two restrictive assumptions that could render its estimates unreliable. First, such a

\footnotetext{
${ }^{1}$ The data we used are the data used by John R. Lott, Jr., \& David B. Mustard, Crime, Deterrence, and Right-to-Carry Concealed Handguns, 26 J. Legal Stud. 1 (1997). 
model assumes the effect to be identical across all states that passed such laws during the span of time that is analyzed (the geographic aggregation assumption), and second, such a model assumes the effect to be constant over time (the intertemporal aggregation assumption).

To relax the geographic aggregation assumption, Black and Nagin determine state-specific least-squares estimates of the dummy coefficients that measure the effects of right-to-carry laws on murder, rape, aggravated assaults, and robberies. Very few of their estimates are statistically significantly different from zero, and they conclude that the significance of Lott and Mustard's estimates of aggregate average effects is partly due to an aggregation bias. However, to avoid the bias that is caused by excluding observations on the basis of the dependent variable being zero, they restrict their analysis to large counties (those with populations of at least 100,000 persons), which are likely to report positive numbers of murders, rapes, and robberies in any given year. This practice reduces the number of usable observations by about 85 percent, to 6,009 for murder and 6,173 for robbery. We argue that the lack of statistical significance of Black and Nagin's findings is a result of their restriction of the data to large counties. We repeat their analysis of state-specific effects with the Poisson-lognormal model using all available observations and find state-specific effects of right-to-carry laws to be statistically significantly different from zero in most cases.

To relax the intertemporal aggregation assumption, Black and Nagin use five lead and five lag dummies in place of Lott and Mustard's single dummy that indicates whether a state has adopted right-to-carry laws. In Black and Nagin's least-squares analysis, the coefficients of these dummies and their standard errors are such that they do not indicate any statistically significant impact of right-to-carry laws on any of the four crime categories. ${ }^{8}$ John Lott ${ }^{9}$ includes two time trends for the pre- and postlaw periods and reports that for linear as well as for quadratic trends, his least-squares estimates of the two time trends for murder, rape, and robbery are significantly different from zero at the 10 percent level. Because neither of these two analyses takes the count nature of the crime data into account, we argue that these results are likely to be unreliable.

In this paper, we estimate a more general model that relaxes the geographical and the intertemporal aggregation assumptions simultaneously, and we show that there is substantial variation of the effects of right-to-carry laws across states and across the three crime categories of murder, rape, and robbery. Our analysis suggests that right-to-carry laws have statistically significant deterrent effects on crimes in these categories in at least half of the 10 states that have adopted such laws, but it also indicates that in some states

\footnotetext{
${ }^{8}$ Black \& Nagin, supra note 5, at 216, table 2.

${ }^{9}$ John Lott, Jr., More Guns, Less Crime: Understanding Crime and Gun-Control Laws 73 n.36 (1998).
} 
TABLE 1

Distributions of the Numbers of Murders, Rapes, Robberies, Aggravated Assaults, and Burglaries in LotT and Mustard's Data Set

\begin{tabular}{lrrrrrrrrrrrrr}
\hline \hline Crime & \multicolumn{1}{c}{0} & 1 & 2 & 3 & \multicolumn{1}{c}{4} & \multicolumn{1}{c}{5} & 6 & 7 & 8 & 9 & 10 & $>10$ & Total \\
\hline Murder & 20,213 & 8,380 & 4,892 & 2,891 & 2,000 & 1,375 & 1,019 & 807 & 581 & 475 & 372 & 3,956 & 46,925 \\
Rape & 11,880 & 6,135 & 4,237 & 2,980 & 2,266 & 1,690 & 1,425 & 1,124 & 1,003 & 865 & 657 & 11,851 & 46,111 \\
Robbery & 11,563 & 5,547 & 3,826 & 2,680 & 1,981 & 1,622 & 1,260 & 1,077 & 947 & 776 & 666 & 14,980 & 46,925 \\
Assault & 2,678 & 1,848 & 1,603 & 1,462 & 1,215 & 1,327 & 1,112 & 1,009 & 960 & 810 & 824 & 32,063 & 46,911 \\
Burglary & 258 & 219 & 268 & 248 & 268 & 240 & 245 & 272 & 246 & 275 & 318 & 44,068 & 46,925 \\
\hline
\end{tabular}

the effect of adopting a right-to-carry law may be an increase in crimes in some categories.

Section II of this paper motivates the use of count-data models and of a Poisson-lognormal model in particular for analyzing the effects of right-tocarry laws on the numbers of various crimes. Section III summarizes and discusses our model specifications and our estimation results, and Section IV presents our conclusions.

\section{The Need for a Count Model to Analyze Infrequent Crimes}

Table 1 shows distributions over county-years of the numbers of reported murders, rapes, robberies, aggravated assaults, and burglaries between 1977 and 1992. For murder, more than 40 percent of all observations are zero, and more than half are either zero or one. For rape, 25 percent of all observations are zero, and almost half of the observations are not above two. Robbery has a similar distribution: about 25 percent of the observations are zero, and half are not more than three. For aggravated assaults, however, only 5 percent of all observations are zero and only about 30 percent are below 11, and for burglary, less than 1 percent of all observations are zero and only 6 percent are below 11 . The very large proportions of zeros in the cases of murders, rapes, and robberies imply that valid distributions of these data sets will have substantial mass points at zero for many counties, and an adequate statistical analysis of these data must take this into account.

One might think that a model that excludes all county-years without any crime in the category being analyzed circumvents this problem. But this only prevents the problem from becoming visible. The exclusion would not bias the results if zero-crime observations were as likely under a right-to-carry law as without one. However, this is not true if right-to-carry laws make a difference; the fact that a county does not experience a certain crime during a year is a piece of information in itself, and eliminating such observations, 
especially in cases where nearly half of the observations fall into this category, yields unreliable results. ${ }^{10}$

Lott and Mustard ${ }^{11}$ acknowledge this problem and repeat their least-squares analysis with a Tobit model, which assumes that the distribution of the data is censored normal (that is, the data are normally distributed for values larger than zero, and everything that would be to the left of zero is assigned to a mass point at zero). Their Tobit analysis suffers from the problem that their computer estimation program (STATA) does not permit the use of dummy variables for all 3,054 counties in a Tobit analysis. Because their least-squares results indicate that counties are sufficiently heterogeneous to warrant the use of such a model as long as sufficient information about possible determinants of the number of crimes is not available on the county level, the results of their Tobit analysis are unreliable. ${ }^{12}$

It is more promising to accommodate the fact that county-level data for important crimes are mostly small nonnegative integers by undertaking statistical analyses in which the dependent variable is the actual number of crimes rather than the crime rate. ${ }^{13}$ The distribution of the dependent variable is then modeled as a series of mass points at nonnegative integers instead of a continuous distribution or a continuous distribution plus a single mass point. The statistical analysis of such models is called count-data analysis.

The standard approach to count-data analysis is to use a maximumlikelihood estimation technique together with the (discrete) Poisson distribution. ${ }^{14}$ Although the Poisson distribution describes only data with a variance equal to its mean (null dispersion), the Poisson regression model has the advantage that, even if the assumption of null dispersion is incorrect, (quasi) maximum-likelihood methods yield consistent estimates of the model co-

\footnotetext{
${ }^{10}$ Even if it were true that the zero-crime county-years were otherwise typical, in cases where about half of the county-years do not show a single occurrence of the crime, the explanatory power of such a model would be lower than that of a valid analysis that uses these observations.

${ }^{11}$ Lott \& Mustard, supra note 1.

${ }^{12}$ Even a fixed-effects Tobit model would be misspecified in this case, because the Tobit model assumes that the data are censored (meaning that, while in principle the dependent variable can have any value, values below a certain threshold value are recorded as this threshold value), whereas the crime data can at best be interpreted as truncated (it is not possible to have a negative number of crimes). Applying the Tobit model to truncated data yields biased estimates, even when the assumption of normality is valid (see G. S. Maddala, Introduction to Econometrics 341-42 (2d ed. 1992)).

${ }^{13}$ Although it would be possible to attempt to estimate the impact of right-to-carry laws on crime as an ordered probit or logit model, we do not consider such models to be a viable alternative to a count analysis in the present case. Ordered probit or logit models are used to describe latent dependent variables that are theoretically continuous but are coded as ordered integers for convenience, and we find it difficult to motivate the idea that the number of crimes is analyzed best as the discrete outcome of an otherwise continuous choice process.

${ }^{14}$ See, for example, Rainer Winkelmann \& Klaus F. Zimmermann, Recent Developments in Count Data Modeling: Theory and Application, 9 J. Econ. Surveys 1 (1995); and Adrian Colin Cameron \& Pravin K. Trivedi, Regression Analysis of Count Data (1998).
} 
efficients as long as the conditional mean is correctly specified. If the true data-generating process is Poisson, the maximum-likelihood estimates are efficient. ${ }^{15}$

To illustrate the importance of the distributional assumptions in this case, and to demonstrate that the problem of distributional misspecification does not disappear as the sample becomes very large, we simulated data that are similar to the data on crime and estimated the coefficients of the generating process, using different methods. ${ }^{16}$ Because the expected number of crimes cannot be negative, we generated our simulated data by a Poisson process ${ }^{17}$ and used

$$
E\left(y_{i} \mid x_{i}\right)=\exp \left(\alpha+\beta x_{i}\right)
$$

as the expected value of observation $i$. In this expression, $\alpha$ is an intercept term and $\beta$ is the coefficient of a dummy variable $x$ that takes values of either one or zero (that is, right-to-carry laws either have or have not been adopted). We set $\alpha=0$ and $\beta=.5$ and sampled 50,000 observations from a Poisson distribution, using equation (1) to specify the single parameter (the mean and the variance) of the Poisson distribution; one-half of the observations were sampled with $x_{i}=1$ and the other half with $x_{i}=0$. This simulated data set had 14,005 zeros and 35,995 values between 1 and 9. We then used ordinary least squares (OLS), the Tobit model, the probit model, and the Poisson model to estimate $\alpha$ and $\beta$. The results are reported in Table 2.

Column 2 corresponds to Lott and Mustard's suggestion of eliminating all observations with zero crimes and estimating the regression equation $\ln y_{i}=\alpha+\beta x_{i}$ with least squares. For our simulated data, the OLS estimate of $\beta$ is 52 standard deviations from the true value. Including the zero observations by replacing all zeros by .1 (column 3 ) does not produce adequate estimates either. ${ }^{18}$ Estimating the regression equation $y_{i}=\alpha+\beta x_{i}$ with the Tobit model (column 4) yields a better estimate of $\beta$, but the estimate is still 3.5 standard errors from the true value of .5. Because there is no reason to eliminate all zero observations if the Tobit model is used, we estimated the

\footnotetext{
${ }^{15}$ See Christian Gourieroux, Alain Monfort, \& Alain Trognon, Pseudo Maximum Likelihood Methods: Application to Poisson Models, 52 Econometrica 701, 712 (1984). If the assumption of null dispersion is incorrect, it is necessary to correct the estimate of the standard errors of such a misspecified model, for example, by the method developed by Halbert White, Maximum Likelihood Estimation of Misspecified Models, 50 Econometrica 1 (1982), or by the method of Peter McCullagh \& John A. Nelder, Generalized Linear Models (2d ed. 1989).

${ }^{16}$ See Jerry Hausman, Bronwyn H. Hall, \& Zvi Griliches, Econometric Models for Count Data with an Application to the Patents-R\&D Relationship, 52 Econometrica 909 (1984), for another comparison of OLS and Poisson estimates.

${ }^{17}$ Although the use of other data-generating processes is possible, the Poisson process is the standard process used in count-data analyses.

${ }^{18}$ In specifications that do not include the arrest rate, Lott \& Mustard treat 0 crimes as .1 crimes to avoid taking the logarithm of zero. See supra note 1.
} 
DETER COUNTABLE CRIMES?

TABLE 2

Estimation of Simulated Data with Several Estimation Methods

\begin{tabular}{|c|c|c|c|c|c|c|c|}
\hline & $\begin{array}{c}\text { True } \\
\text { Values } \\
\text { (1) }\end{array}$ & $\begin{array}{c}\text { OLS: } \\
\text { Eliminate } \\
\text { Zero Values } \\
\text { (2) }\end{array}$ & $\begin{array}{l}\text { OLS: } \\
\text { Set Zero } \\
\text { Values } \\
\text { to .1 } \\
\text { (3) }\end{array}$ & $\begin{array}{c}\text { Tobit: } \\
\text { Eliminate } \\
\text { Zero Values } \\
\quad \text { (4) }\end{array}$ & $\begin{array}{l}\text { Tobit: } \\
\text { Set Zero } \\
\text { Values } \\
\text { to .1 } \\
\text { (5) }\end{array}$ & $\begin{array}{l}\text { Probit } \\
\text { (6) }\end{array}$ & $\begin{array}{l}\text { Poisson } \\
\text { (7) }\end{array}$ \\
\hline$\alpha$ & 0 & $\begin{array}{c}.3532 \\
(.0039)\end{array}$ & $\begin{array}{l}1.5856 \\
(.0079)\end{array}$ & $\begin{array}{c}-.6263 \\
(.0081)\end{array}$ & $\begin{array}{c}-.9916 \\
(.0116)\end{array}$ & $\begin{array}{c}.3452 \\
(.0081)\end{array}$ & $\begin{array}{c}.0069 \\
(.0063)\end{array}$ \\
\hline$\beta$ & .5 & $\begin{array}{l}.2235 \\
(.0052)\end{array}$ & $\begin{array}{l}.4552 \\
(.0105)\end{array}$ & $\begin{array}{l}.6525 \\
(.0115)\end{array}$ & $\begin{array}{c}.8592 \\
(.0159)\end{array}$ & $\begin{array}{l}.5250 \\
(.0122)\end{array}$ & $\begin{array}{c}.4932 \\
(.0079)\end{array}$ \\
\hline $\begin{array}{l}N \\
R^{2} \text { or log }\end{array}$ & & 36,074 & 50,000 & 36,074 & 50,000 & 50,000 & 50,000 \\
\hline likelihood & & .0532 & .0610 & $-36,395$ & $-85,320$ & $-28,636$ & $-72,526$ \\
\hline
\end{tabular}

NOTE. - Estimated standard errors are shown in parentheses. OLS $=$ ordinary least squares.

Tobit model again using all 50,000 observations (column 5); the estimate of $\beta$ is 25 standard deviations from the true value. The probit model yields a better estimate of $\beta$, but it is still 2 standard errors from the true value (column 6). ${ }^{19}$ Not surprisingly, the Poisson model yields the most precise estimate of $\beta$ (column 7). ${ }^{20}$ The exercise provides evidence that the models used by previous researchers who have undertaken statistical analyses of county-level murder, rape, and robbery rates are unreliable for determining whether rightto-carry laws have a statistically significant impact on the numbers of these crimes.

The assumption that the crime data are Poisson distributed is equivalent to assuming that the probability of a crime in a small interval of time is constant in a county during a year and that this probability depends on a county-specific constant, a year-specific constant, and on several independent variables whose impacts on the expected number of crimes have the same functional form across counties. But it is also possible that the probability of a crime in a small interval of time in a county fluctuates and thus follows

\footnotetext{
${ }^{19}$ The use of the probit model as an alternative specification was suggested to us by Glen Harrison.

${ }^{20}$ In interpreting these results, one needs to keep in mind that the simulated data represent one single realization of a sample of 50,000 observations from a Poisson distribution and that different samples from the same distribution will yield different estimates. It is therefore not so relevant whether the estimation method is able to exactly estimate the true coefficient (because different samples drawn from the same distribution will yield different estimates of the coefficients), but rather whether the 95 percent confidence interval includes the true value and, if that criterion is met, whether the standard error of estimate is small. Ordinary least squares and the Tobit model both fail with respect to the first criterion. This exercise does not prove that estimation methods that assume a continuous distribution will generally fail to yield reliable estimates for count-data problems with many zeros, because we have created only a single sample of simulated data; a more rigorous analysis would compare the reliability of the different methods over a variety of samples with different values of $\alpha$ and $\beta$.
} 
a county-specific distribution, which would mean that the parameter of the Poisson distribution is not deterministic but a random variable itself.

The standard model for such cases is the negative binomial model, which corresponds to the assumption that the Poisson parameter varies according to a gamma distribution and implies that the data have a variance that is larger than their mean (the data are overdispersed). ${ }^{21}$ However, the asymmetry of the log of the gamma distribution implies that, if the Poisson parameter is assumed to be gamma distributed, an increase by a factor of $x$ is less likely than a decrease by a factor of $x$. In the context of the current problem, this means that a county in which, for example, 20 murders per year are expected on average is more likely to have a year in which 16 murders are expected than one in which 25 are expected. In the absence of further information about the variation of the number of murders, this assumption of log asymmetry is rather arbitrary, and it is more intuitive to assume that an increase and a decrease by a factor of $x$ are equally likely. ${ }^{22}$

This can be achieved by assuming that the Poisson parameter follows a lognormal distribution, which has the log symmetry that the gamma distribution lacks. While a maximum-likelihood analysis of a model with this distribution would be fairly complex, it is nevertheless possible to estimate the coefficients of this model with alternative estimation methods. A Markov chain Monte Carlo method, the Gibbs sampler, lends itself naturally to this kind of problem. Because the Poisson-lognormal model takes the overdispersion of the data explicitly into account, one can expect that it will yield smaller standard errors than a Poisson model whose standard errors have been corrected with the standard methods. In a previous analysis of count data, we found that implementing a Poisson-lognormal model with a Gibbs sampler yielded estimates of the standard errors of coefficients that were significantly smaller than those estimated for a Poisson model by a maximumlikelihood method. ${ }^{23}$

While least-squares and maximum-likelihood methods assume that the coefficients in a statistical model are deterministic numbers, Markov chain Monte Carlo methods are based on the more realistic assumption that these coefficients are random variables themselves, which means that not only the

\footnotetext{
${ }^{21}$ Although the Poisson estimates of the coefficient means are consistent for overdispersed data, the correction of the standard deviation does not take the information about dispersion into account. When there is overdispersion, a model that uses this additional information can improve on the estimated standard deviation of the misspecified Poisson model.

${ }^{22}$ The Poisson and gamma distributions have a natural relationship: if the number of events follows a Poisson distribution, the time intervals between these events are gamma distributed. Without further motivation, however, this does not justify the assumption that the Poisson parameter itself is gamma distributed, and the assumption is usually made for computational convenience only.

${ }^{23}$ Florenz Plassmann \& T. Nicolaus Tideman, A Markov Chain Monte Carlo Analysis of the Effect of Two-Rate Property Taxes on Construction, 47 J. Urb. Econ. 216 (2000).
} 
data but also the coefficients are samples drawn from specific distributions. ${ }^{24}$ In the present example, we assume that the numbers of crimes are generated by a Poisson process whose single parameter follows a lognormal distribution, which is equivalent to assuming that the coefficients of the exponential regression equation $-\alpha$ and $\beta$ in equation (1) - follow normal distributions. ${ }^{25}$

Besides their capacity to model nonstandard distributions, Markov chain Monte Carlo methods have another advantage for the estimation problem at hand. Standard computer estimation packages make it difficult, and in some cases impossible, to estimate nonlinear models with many dummy variables. Markov chain Monte Carlo methods do not require the maximization of a likelihood function and are therefore very attractive for the analysis of models with several thousand explanatory variables and observations. ${ }^{26}$

\section{The EMPIRICAL Evidence}

\section{A. Selection of Variables}

John Lott and David Mustard's data set contains information for 3,054 counties in the United States for the years 1977-92. Their most widely quoted

\footnotetext{
${ }^{24}$ The assumption that the coefficients are random variables transforms what would otherwise be a fixed-effects model into a random-effects model.

${ }^{25}$ The function that would be required by maximum-likelihood methods is the joint density function of the Poisson-distributed data and the normally distributed coefficients of the regression equation. Although a closed-form solution for this joint density has not been discovered yet (and might not even exist), it can be described through the full conditional distributions of all coefficients in the model (the distributions of individual coefficients, conditional on the values of all other coefficients and on the data), which can easily be determined in this case. These full conditional distributions provide sufficient information for the Gibbs sampler to approximate numerically the unknown joint distribution by creating Markov chains of samples that are drawn from the full conditional distributions. Because of their Markov properties, these chains of samples ultimately converge to samples that are drawn from the true marginal (that is, unconditional) distributions of the coefficients, and these samples can be used to draw inferences about these distributions, for example, about the means and the variances of the coefficients. For descriptions and discussion of Markov chain Monte Carlo methods and the Gibbs sampler, see George Casella \& Edward I. George, Explaining the Gibbs Sampler, 46 Am. Stat. 167 (1992); Alan E. Gelfand \& Adrian F. M. Smith, Sampling-Based Approaches to Calculating Marginal Densities, 85 J. Am. Stat. Ass'n 398 (1990); and Walter R. Gilks, Sylvia Richardson, \& David J. Spiegelhalter, Markov Chain Monte Carlo in Practice (1996).

${ }^{26}$ One might question the consistency of the estimators of our random-effects count model because of the incidental parameters problem. Cameron \& Trivedi, supra note 14, at 281-82, shows that it is possible to derive consistent maximum-likelihood estimators for fixed-effects Poisson models. However, we are not aware of any work that formally addresses the consistency of Gibbs sampler estimates in nonlinear random-effects models. We undertook another Monte Carlo experiment for which we sampled 48,000 observations from a model with 3,000 groups and 16 observations per group. In terms of equation (1), we assumed that each group had a different intercept $\alpha$ (which we sampled from a normal distribution with mean and variance equal to one) and an identical $\beta=.5$. We then estimated all random effects and $\beta$ using our Gibbs sampler model. We repeated this experiment 100 times; the average value of $\beta$ was .49992 with an estimated standard error of .0087 . This experiment suggests that the Gibbs sampler estimates of the right-to-carry dummy in our random-effects model are consistent.
} 
TABLE 3

IndePEndent Variables Included in Lott AND Mustard's and IN This Analysis

\begin{tabular}{|c|c|c|c|c|}
\hline & \multirow{2}{*}{$\begin{array}{l}\text { LOTT AND } \\
\text { MUSTARD'S } \\
\text { ANALYSIS } \\
\text { (1) }\end{array}$} & \multicolumn{3}{|c|}{ This Analysis } \\
\hline & & $\begin{array}{l}\text { Murder } \\
(2)\end{array}$ & $\begin{array}{l}\text { Rape } \\
(3)\end{array}$ & $\begin{array}{c}\text { Robbery } \\
\text { (4) }\end{array}$ \\
\hline County dummies & + & + & + & + \\
\hline Year dummies & + & + & + & + \\
\hline Dummy variable to indicate whether & & & & \\
\hline right-to-carry law was in effect & + & + & + & + \\
\hline Arrest rate & + & & & \\
\hline County population & + & & & \\
\hline Population density & + & & & \\
\hline $\ln$ (Population density) & & + & + & + \\
\hline Real personal income per capita & + & & & \\
\hline $\ln ($ Real personal income per capita) & & + & + & + \\
\hline $\begin{array}{l}\text { Real per capita unemployment insurance } \\
\text { payments }\end{array}$ & + & & & \\
\hline $\begin{array}{l}\text { Real per capita income maintenance } \\
\text { payments }\end{array}$ & + & & & \\
\hline $\begin{array}{l}\text { Real per capita retirement payments for } \\
\text { persons over } 65 \text { years of age }\end{array}$ & + & & & \\
\hline 36 demographic variables $^{\mathrm{a}}$ & + & & & \\
\hline Logs of the 36 demographic variables & & & + & \\
\hline Percentage of county population that is white ${ }^{b}$ & & + & & \\
\hline Percentage of county population that is black $\mathrm{b}^{\mathrm{b}}$ & & + & & + \\
\hline
\end{tabular}

${ }^{a}$ The demographic variables describe the percentage composition of the county population in terms of all possible combinations of gender, race (white, black, neither white nor black), and age over 10 (10-19, $20-29,30-39,40-49,50-64$, and over 64 years of age).

b The data set contains another category, "neither black nor white," so no multicollinearity problem arises if both the percentage black and the percentage white are included in the analysis.

model specification uses the logarithm of the ratio of crimes to population as the dependent variable, treating 0 crimes as .1 crimes to avoid taking the logarithm of zero. The independent variables that they use in their analysis are shown in column 1 of Table 3 . One of these independent variables is the arrest rate. For any crime category in any county-year, the arrest rate is calculated as the ratio of the number of arrests to the number of crimes in that category in that county-year and is therefore not defined whenever the county does not experience any crimes in that category during that year. In the case of murder, using the arrest rate as an independent variable results in the elimination of 44 percent of all observations, and the significance of the right-to-carry dummy in Lott and Mustard's least-squares analyses of murder depends on this elimination of all county-years without murders. However, for rape, the use of the arrest rate leads to the elimination of only 27 percent of the data, and for robbery of only 25 percent of the data. The effects of eliminating the arrest rate in the analyses of murder, rape, and robbery are shown in the first three columns of Table 4. Column 1 is a replication of Lott and Mustard's most widely quoted estimates as reported 
TABLE 4

Aggregate Impacts of Right-to-Carry Laws on Murder, Rape, and Robbery

\begin{tabular}{|c|c|c|c|c|c|c|}
\hline & \multicolumn{5}{|c|}{ Normal Model (Estimated with Weighted Least Squares) } & \multirow{2}{*}{$\begin{array}{l}\text { PoIsSON-LOGNORMAL MODEL } \\
\text { Repeat (5) with the } \\
\text { Poisson-Lognormal Model } \\
\text { (Using the Gibbs Sampler) } \\
\text { (6) }\end{array}$} \\
\hline & $\begin{array}{c}\text { Repetition of } \\
\text { Lott and Mustard's } \\
\text { Specification from } \\
\text { Their Table } 3 \\
\text { (1) }\end{array}$ & $\begin{array}{l}\text { Repeat (1) } \\
\text { without the } \\
\text { Arrest Rate } \\
\quad \text { (2) }\end{array}$ & $\begin{array}{c}\text { Repeat (2) } \\
\text { with All } \\
\text { Observations } \\
\text { (3) }\end{array}$ & $\begin{array}{l}\text { Repeat (3) } \\
\text { with Fewer } \\
\text { Independent } \\
\text { Variables } \\
\text { (4) }\end{array}$ & $\begin{array}{c}\text { Repeat (4) } \\
\text { Using Counties } \\
\text { with at Least } \\
\text { One Crime } \\
\text { (5) }\end{array}$ & \\
\hline \multicolumn{7}{|l|}{ Murder: } \\
\hline Right-to-carry dummy & $\begin{array}{c}-.0729 \\
(-.0156)\end{array}$ & $\begin{array}{c}-.0675 \\
(.0161)\end{array}$ & $\begin{array}{r}-.0190 \\
(.0269)\end{array}$ & $\begin{array}{c}-.0183 \\
(.0276)\end{array}$ & $\begin{array}{c}-.0198 \\
(.0263)\end{array}$ & $\begin{array}{c}-.1115 \\
(.0111)\end{array}$ \\
\hline Total number of independent variables & 2,975 & 2,974 & 3,179 & 3,129 & 2,988 & 2,988 \\
\hline$N$ & 26,380 & 26,380 & 46,883 & 46,883 & 44,614 & 44,614 \\
\hline Adjusted $R^{2}$ & .8065 & .7948 & .6276 & .6189 & .6206 & \\
\hline \multicolumn{7}{|l|}{ Rape: } \\
\hline Right-to-carry dummy & $\begin{array}{r}-.0520 \\
(.0122)\end{array}$ & $\begin{array}{c}-.0571 \\
(.0127)\end{array}$ & $\begin{array}{c}-.0520 \\
(.0227)\end{array}$ & $\begin{array}{c}-.0514 \\
(.0224)\end{array}$ & $\begin{array}{c}-.0516 \\
(.0227)\end{array}$ & $\begin{array}{l}-.0410 \\
(.00541)\end{array}$ \\
\hline Total number of independent variables & 3,094 & 3,093 & 3,180 & 3,175 & 3,099 & 3,099 \\
\hline$N$ & 33,865 & 33,865 & 46,144 & 46,144 & 45,450 & 45,450 \\
\hline Adjusted $R^{2}$ & .8005 & .7858 & .6616 & .6613 & .6572 & \\
\hline \multicolumn{7}{|l|}{ Robbery: } \\
\hline Right-to-carry dummy & $\begin{array}{c}-.0225 \\
(.0134)\end{array}$ & $\begin{array}{c}-.0109 \\
(.0145)\end{array}$ & $\begin{array}{c}.0152 \\
(.0217)\end{array}$ & $\begin{array}{c}.0141 \\
(.0208)\end{array}$ & $\begin{array}{l}.0140 \\
(.0210)\end{array}$ & $\begin{array}{c}.0559 \\
(.0249)\end{array}$ \\
\hline Total number of independent variables & 3,062 & 3,061 & 3,180 & 3,141 & 3,039 & 3,039 \\
\hline$N$ & 34,949 & 34,949 & 46,957 & 46,957 & 45,952 & 45,952 \\
\hline Adjusted $R^{2}$ & .9197 & .9001 & .8320 & .8284 & .8257 & \\
\hline
\end{tabular}

NoTE. - Least-squares estimates in columns 1-5 are weighted by county population to accommodate heteroskedasticity. Estimated standard errors are shown in parentheses. 
in their table $4 .^{27}$ Column 2 shows the effects of omitting the arrest rate if the same numbers of observations as in column 1 are used, and column 3 shows the estimates of the right-to-carry coefficient if the arrest rate is excluded and all available observations are used. For rape, the estimate does not change, remaining significantly less than zero, but for murder and robbery the estimate increases by more than two of column 1's standard errors; the estimate for murder remains negative but becomes insignificant, and the estimate for robbery remains insignificant and becomes positive. This indicates that in the cases of murder and robbery, the elimination of 56 and 25 percent of all observations that are zero leads to a sample selection bias but that no such bias is introduced into the analysis of rape if the corresponding 27 percent of all observations are excluded.

In a Gibbs sampler analysis of a Poisson-lognormal distribution, adding dummy variables does not increase the running time of the algorithm by very much, but adding nondummy independent variables is very time consuming for a data set with more than 45,000 observations. ${ }^{28}$ To obtain estimates of the impact of right-to-carry laws for the Poisson-lognormal model with the Gibbs sampler within a reasonable amount of time, we needed to reduce the number of independent nondummy variables by as much as possible. To prevent the exclusion of variables that are correlated with the right-to-carry dummy, we tried to find combinations of independent variables that yielded weighted least squares estimates of the coefficients of the right-to-carry dummy that were as close as possible to the estimates of the full model shown in column 3 of Table $4 .{ }^{29}$ For the categories of robbery and murder, we were able to replicate the estimate with only three and four, respectively, nondummy variables, while the category of rape required the full set of

\footnotetext{
${ }^{27}$ It has been suggested to us that this model will be not yield reliable results because it does not account for the probability of being arrested and convicted and for the severity of punishment if convicted. However, the omission of the arrest rate as well as the omission of the (entirely unknown) conviction rates and severity of punishment will introduce a bias only if these omitted variables vary in ways that differ among counties and are correlated with the right-to-carry dummy.

${ }^{28}$ This is explained in greater detail in a supplemental paper, which is available from the authors on request and which shows the distributions from which one needs to sample.

${ }^{29}$ The specifications in the first three columns use the log of the number of crimes per 100,000 persons as the dependent variable but do not use log transformations of any of the independent variables, which implies exponential relationships between the crime rates and the independent variables. This relationship is unsatisfying for the county population because if two counties were to be combined into a single county, the expected number of crimes in the new larger county should be equal to the sum of the expected numbers of crimes in the two smaller counties. This additivity can be achieved only when population enters the regression equation multiplicatively with a coefficient of 1 , or, equivalently, if the dependent variable number of crimes is divided by the county population and the county population is not included again among the independent variables. We therefore excluded the county population from the subsequent least-squares analyses. To provide for the possibility that population is correlated with omitted variables, we included the log of population density with an unrestricted coefficient in the regression equation.
} 
demographic variables. The sets of independent variables that were included in the analyses for each crime category are shown in columns 2-4 of Table 3 , and our weighted least squares estimates of the coefficient of the rightto-carry dummy with the reduced sets of independent variables are shown in column 4 of Table 4; the estimates of the coefficients of the right-to-carry dummies are virtually unchanged compared with those in column 3 .

\section{B. Aggregate and State-Specific Effects of Right-to-Carry Laws on Murder, Rape, and Robbery}

Instead of using the crime rate as the dependent variable, we use the numbers of murders, rapes, and robberies each as dependent variables and assume that these numbers were drawn from Poisson-lognormal distributions. Because the expected numbers of crimes cannot be negative, we express the expected number of crimes in any given category in county $c$ in year $t$ as

$$
\mu_{\mathrm{ct}}=\mathrm{POP}_{\mathrm{ct}} \exp \left(\alpha+\beta \mathrm{RTCD}_{\mathrm{ct}}+\gamma X_{\mathrm{ct}}+\mathrm{YD}_{t}+\mathrm{CD}_{c}\right),
$$

where $\mathrm{POP}_{\mathrm{ct}}$ is population, $\mathrm{RTCD}_{\mathrm{ct}}$ is the right-to-carry dummy, $X_{\mathrm{ct}}$ is the vector of the logarithms of the independent nondummy variables, $\gamma$ is a vector of the coefficients of these variables, $\mathrm{YD}_{t}$ is the coefficient of the $t$ th year dummy, and $\mathrm{CD}_{c}$ is the coefficient of the cth county dummy. The multiplicative treatment of $\mathrm{POP}_{\mathrm{ct}}$ is equivalent to introducing the $\log$ of $\mathrm{POP}_{\mathrm{ct}}$ in an exponential equation with a coefficient restricted to be 1 . This restriction is plausible, because if two counties were to be combined into a single county, the expected number of murders in the new larger county should be equal to the sum of the expected numbers of murders in the two smaller counties; this can be achieved only when population enters the regression equation multiplicatively. An estimated coefficient different from 1 would indicate that population is correlated with omitted variables; to account for this possibility, we include the log of population density with an unrestricted coefficient in the regression equation. ${ }^{30}$

The multiplicative form of the regression equation makes it necessary to eliminate all observations from counties that did not report any crimes in the examined category for any of the years from 1977 to 1992. The coefficients of the county dummies measure the average expected numbers of crimes in this category for each county, and introducing the county dummies in exponential form implies that the best estimate of the coefficients of the dummies of counties without any reported crimes in a given category would be minus infinity, resulting in perfect prediction of crime rates for these counties. Thus, the inclusion of these counties would not contribute anything

\footnotetext{
${ }^{30}$ Because density is defined as $\mathrm{POP}_{\mathrm{ct}} / \mathrm{Area}_{\mathrm{ct}}$, and $\mathrm{Area}_{\mathrm{ct}}$ is constant for a county, the substitution of the $\log$ of population for the log of density as a variable would affect only the coefficients of this variable and of the county dummies. It would not affect the coefficients of the other independent variables or the coefficient of the right-to-carry dummy.
} 
to the analysis, but the effort to reach minus infinity would prevent convergence. We therefore eliminated all counties without any reported crimes, which resulted in the elimination of data from 141 counties for the analysis of murder, 77 counties for the analysis of rape, and 102 counties for the analysis of robbery. To ensure that the elimination of these data does not bias our analysis, we repeated our least-squares analysis with the reduced data sets; column 5 of Table 4 reports the estimates of the coefficients of the right-to-carry dummies. Comparison between columns 4 and 5 indicates that the elimination of counties without any crimes in the examined category has only a very minor impact on the estimates of the coefficients of the rightto-carry dummies, which means that it is unlikely to introduce a sample selection bias into the analysis.

The estimation results of our Poisson-lognormal model are reported in column 6 of Table 4 . The coefficient of -.1115 for murder means that we estimate that right-to-carry laws reduce the number of murders by a factor of $e^{-.1115}$, which is a reduction of 1.55 percent. Similarly, our estimates indicate a decrease of the number of reported rapes by a factor of $e^{-.0410}$ (a reduction of 4.02 percent) and an increase in the number of robberies by a factor of $e^{.0559}$ (an increase of 5.70 percent). For murder, the estimated effect is about five times as large as the least-squares estimate in column 5 , and the standard error of estimate has been reduced by one-half. ${ }^{31}$ For rape, the estimated effect is about 20 percent smaller than the least-squares estimate in column 5, and the standard error of estimate has been reduced fourfold. Like the least-squares estimate, the Poisson-lognormal estimate suggests that there is a negative average effect of right-to-carry laws on the number of reported rapes, but because the standard error of estimate is only one-fourth of the standard error of the least-squares model, the estimate is more precise. For robbery, the estimated effect is about four times larger than the leastsquares estimate in column 5 , and statistically significant, where the leastsquares estimate was not.

We next consider Black and Nagin's suggestion that a model that estimates the impact of right-to-carry laws as a nationwide aggregate might be subject to a geographical aggregation bias and that a disaggregate analysis that estimates state-specific effects will yield more reliable results. We extend our

\footnotetext{
${ }^{31}$ For comparison purposes, we estimated equation (2) with maximum likelihood under the assumption that the number of murders follows a Poisson process and corrected the standard error of estimate using White's method (see White, supra note 15; and Winkelmann \& Zimmermann, supra note 14). The maximum-likelihood estimate of the right-to-carry coefficient was -.1167 with a standard error of .0110 , which suggests that our Gibbs sampler estimates are reasonable. Because of the difficulty involved with the maximization of a likelihood function over several thousand dimensions, we assumed for all subsequent analyzes that the Poissonlognormal model is a suitable approximation of the true underlying model and estimated the coefficients only with the Gibbs sampler.
} 
model to include state-specific coefficients of the right-to-carry dummy and all nondummy variables, respecifying the regression equation as

$$
\mu_{\mathrm{ct}}=\mathrm{POP}_{\mathrm{ct}} \exp \left(\alpha_{s}+\beta_{s} \mathrm{RTCD}_{\mathrm{ct}}+\gamma_{s} X_{\mathrm{ct}}+\mathrm{YD}_{t}+\mathrm{CD}_{c}\right) \text {. }
$$

For each state, we estimated a different intercept and different values of the coefficients of the independent variables; an $s$ subscript indicates that the coefficient is state specific. The estimates of the $\beta$ coefficients for murder, rape, and robbery for the 10 states that adopted right-to-carry laws between 1977 and 1992 are reported in Table 5, together with Black and Nagin's estimates. ${ }^{32}$

Our estimates indicate that the effects of right-to-carry laws vary across states and crime categories. Florida is the only state with significantly negative estimates of the coefficients of the right-to-carry dummies for all three crime categories; for all other states, either some of the coefficients are insignificantly different from zero or the coefficients vary in sign. For murder, the coefficients of three states (Florida, Georgia, and Oregon) are significantly negative, and only for Virginia does the analysis suggest that a right-to-carry law led to a significant increase in the number of murders. For rape, the coefficients are statistically significantly negative for Florida and Georgia only and significantly positive for Idaho, Mississippi, and Pennsylvania. For robbery, all but Georgia's and Mississippi's coefficients indicate a statistically significant decrease in the number of robberies.

The eleventh and twelfth rows in Table 5 show weighted means of the coefficients of all states, weighting each state by its 1984 population, and the estimated aggregate effects over all states from column 6 of Table 4. For rape, the difference between the mean and the aggregate effect is less than the mean's standard error, which suggests that there is no aggregation bias in the estimate of the aggregate effect of right-to-carry laws on these crimes. For murder, this difference is still less than 2 of the mean's standard errors, which also does not permit the conclusion that the estimate of the aggregate is subject to aggregation bias. The mean for robbery, however, is almost 8.5 standard errors below the estimated aggregate effect, which implies that the undifferentiated model is misspecified and that, at least for robbery, the hypothesis that an aggregate effect can be estimated without bias must be rejected.

Comparison of Black and Nagin's results with the estimates obtained from the Poisson-lognormal model shows the advantage of using all available observations and of using a model that is more suited for the data at hand, because all of the 30 estimated standard errors of the Poisson-lognormal model are below those of Black and Nagin's model. It is interesting to note similarities between the two models: for 23 of the 30 estimates, the 95 percent confidence interval of Black and Nagin's model includes the estimate of the

${ }^{32}$ Black \& Nagin, supra note 5, at 212, table 1. 
TABLE 5

State-Specific Impacts of Right-to-Carry Laws on Murder, Rape, and Robbery

\begin{tabular}{|c|c|c|c|c|c|c|}
\hline \multirow[b]{2}{*}{ State } & \multicolumn{2}{|c|}{ MURDER } & \multicolumn{2}{|c|}{ RAPE } & \multicolumn{2}{|c|}{ ROBBERY } \\
\hline & $\begin{array}{c}\text { Coefficients } \\
\text { Reported by } \\
\text { Black and Nagin }\end{array}$ & $\begin{array}{c}\text { Coefficients } \\
\text { Estimated with the } \\
\text { Poisson-Lognormal } \\
\text { Model }\end{array}$ & $\begin{array}{c}\text { Coefficients } \\
\text { Reported by } \\
\text { Black and Nagin }\end{array}$ & $\begin{array}{c}\text { Coefficients } \\
\text { Estimated with the } \\
\text { Poisson-Lognormal } \\
\text { Model }\end{array}$ & $\begin{array}{c}\text { Coefficients } \\
\text { Reported by } \\
\text { Black and Nagin }\end{array}$ & $\begin{array}{c}\text { Coefficients } \\
\text { Estimated with the } \\
\text { Poisson-Lognormal } \\
\text { Model }\end{array}$ \\
\hline Florida & $\begin{array}{c}-.277 * \\
(.0553)\end{array}$ & $\begin{array}{c}-.2360^{*} \\
(.0181)\end{array}$ & $\begin{array}{l}-.170 * \\
(.0414)\end{array}$ & $\begin{array}{c}-.1649 * \\
(.0118)\end{array}$ & $\begin{array}{l}.073 \\
(.0532)\end{array}$ & $\begin{array}{c}-.0313 * \\
(.00292)\end{array}$ \\
\hline Georgia & $\begin{array}{c}-.052 \\
(.0743)\end{array}$ & $\begin{array}{r}-.0796^{*} \\
(.0223)\end{array}$ & $\begin{array}{c}-.045 \\
(.0608)\end{array}$ & $\begin{array}{r}-.1582^{*} \\
(.0162)\end{array}$ & $\begin{array}{l}.077 \\
.0794)\end{array}$ & $\begin{array}{l}.0094 \\
(.00538)\end{array}$ \\
\hline Idaho & $\begin{array}{c}-.210 \\
(.2877)\end{array}$ & $\begin{array}{c}-.0575 \\
(.0485)\end{array}$ & $\begin{array}{c}-.097 \\
(.0776)\end{array}$ & $\begin{array}{l}.1033 * \\
(.0372)\end{array}$ & $\begin{array}{c}-.643^{*} \\
(.1178)\end{array}$ & $\begin{array}{c}-.4143^{*} \\
(.0701)\end{array}$ \\
\hline Maine & $\begin{array}{c}.072 \\
(.1412)\end{array}$ & $\begin{array}{c}.0138 \\
(.0437)\end{array}$ & $\begin{array}{c}.036 \\
(.0621)\end{array}$ & $\begin{array}{c}-.0207 \\
(.0383)\end{array}$ & $\begin{array}{c}-.333^{*} \\
(.0808)\end{array}$ & $\begin{array}{c}-.2198^{*} \\
(.0286)\end{array}$ \\
\hline Mississippi & $\begin{array}{l}.054 \\
(.1421)\end{array}$ & $\begin{array}{l}.0460 \\
(.0352)\end{array}$ & $\begin{array}{l}.320 * \\
(.0784)\end{array}$ & $\begin{array}{l}.1134^{*} \\
(.0276)\end{array}$ & $\begin{array}{l}.103 \\
(.1272)\end{array}$ & $\begin{array}{l}.2474 * \\
(.0169)\end{array}$ \\
\hline Montana & $\begin{array}{l}-.367 \\
(.2368)\end{array}$ & $\begin{array}{c}-.0670 \\
(.0543)\end{array}$ & $\begin{array}{c}-.972 * \\
(.4136)\end{array}$ & $\begin{array}{c}-.0357 \\
(.0415)\end{array}$ & $\begin{array}{c}-.139 \\
(.3390)\end{array}$ & $\begin{array}{c}-.2656^{*} \\
(.0668)\end{array}$ \\
\hline
\end{tabular}




\begin{tabular}{|c|c|c|c|c|c|c|}
\hline Oregon & $\begin{array}{l}-.059 \\
(.0522)\end{array}$ & $\begin{array}{c}-.1005^{*} \\
(.0422)\end{array}$ & $\begin{array}{l}.035 \\
(.0515)\end{array}$ & $\begin{array}{r}-.0235 \\
(.245)\end{array}$ & $\begin{array}{c}-.053 \\
(.0338)\end{array}$ & $\begin{array}{c}-.4752 * \\
(.0121)\end{array}$ \\
\hline Pennsylvania & $\begin{array}{c}-.089 \\
(.0881)\end{array}$ & $\begin{array}{c}-.0455 \\
(.0277)\end{array}$ & $\begin{array}{l}.044 \\
(.0286)\end{array}$ & $\begin{array}{l}.1424 * \\
(.0184)\end{array}$ & $\begin{array}{c}-.035 \\
(.0603)\end{array}$ & $\begin{array}{c}-.1372 * \\
(.00642)\end{array}$ \\
\hline Virginia & $\begin{array}{l}.039 \\
(.0830)\end{array}$ & $\begin{array}{l}.0802 * \\
(.0228)\end{array}$ & $\begin{array}{c}-.076 \\
(.0418)\end{array}$ & $\begin{array}{c}-.0255 \\
(.0187)\end{array}$ & $\begin{array}{c}-.121 \\
(.0634)\end{array}$ & $\begin{array}{c}-.0475^{*} \\
(.00648)\end{array}$ \\
\hline West Virginia & $\begin{array}{l}.718^{*} \\
(.1697)\end{array}$ & $\begin{array}{l}.0519 \\
(.0380)\end{array}$ & $\begin{array}{c}-.285^{*} \\
(.1029)\end{array}$ & $\begin{array}{c}-.0109 \\
(.0314)\end{array}$ & $\begin{array}{l}.094 \\
(.1106)\end{array}$ & $\begin{array}{c}-.0883^{*} \\
(.0195)\end{array}$ \\
\hline Mean of all 10 estimates & & $\begin{array}{c}-.0677 \\
(.0292)\end{array}$ & & $\begin{array}{c}-.0208 \\
(.0214)\end{array}$ & & $\begin{array}{c}-.0869 \\
(.0168)\end{array}$ \\
\hline Aggregate effect & & $\begin{array}{c}-.111 \\
(.0111)\end{array}$ & & $\begin{array}{c}-.0410 \\
(.00541)\end{array}$ & & $\begin{array}{l}.0559 \\
(.00249)\end{array}$ \\
\hline Number of observations & 6,009 & 44,614 & 6,036 & 45,450 & 6,109 & 45,952 \\
\hline
\end{tabular}

NoTE. - The aggregate effects are the effects reported in column 6 of Table 4. Estimated standard errors are shown in parentheses.

a Dan A. Black \& Daniel S. Nagin, Do Right-to-Carry Laws Deter Violent Crime? 27 J. Legal Stud. 209 (1998). 
Poisson-lognormal model. This indicates that while the exclusion of small counties (those with a population below 100,000 persons-more than 70 percent of the observations, mostly at the left end of the distribution of crimes) makes it possible to avoid some of the difficulties posed by the integer nature of the data, this greatly reduces the precision of the estimates.

\section{Relaxing the Intertemporal Aggregation Assumption}

The two models in the previous subsection used a single dummy variable to describe the nationwide and the state-specific effects of right-to-carry laws. This dummy variable measures the difference between the average expected numbers of crimes before and after a right-to-carry law had been implemented. However, the use of averages might mask the presence of trends or cycles that could provide a better insight into the effects of the laws. Lott and Mustard ${ }^{33}$ report that use of pre- and postlaw trends indicates a deterrent effect of right-to-carry laws on most violent crimes, but they do not report the results of their regressions; $\operatorname{Lott}^{34}$ reports estimates of trend dummies for violent crimes that suggest that the postlaw trends are significantly more negative that the prelaw trends. ${ }^{35}$

The use of a single coefficient to describe a trend requires the guess of a specific functional form of the trend (usually either linear or quadratic), but the actual trend might be less systematic. A more general approach is therefore to use several dummies for the years around the implementation of the law. Black and Nagin ${ }^{36}$ introduced lead and lag dummies for the 5 years before and the 5 years after a state had implemented a right-to-carry law. Again, they restricted their analyses to counties with populations of more than 100,000 persons to reduce the sample selection bias that is caused by using the arrest rate as an independent variable, thereby eliminating all county-years with zero crimes in the category examined, and they used first differences of all variables to eliminate the need for fixed-effects county dummies. Their analyses did not show a consistent pattern that would indicate deterrent effects of right-to-carry laws.

Comparison between Black and Nagin's and our estimates in Table 5 indicates that eliminating small counties reduces the possibility of finding such effects, because reduction of the number of observations increases the estimates of the standard errors. We therefore used the Poisson-lognormal

\footnotetext{
${ }^{33}$ Lott \& Mustard, supra note 1.

${ }^{34}$ John R. Lott, Jr., The Concealed-Handgun Debate, 27 J. Legal Stud. 221, 239-41 (1998).

${ }^{35}$ Results of a similar analysis are reported in Lott, supra note 9, at 72.

${ }^{36}$ Black \& Nagin, supra note 5.
} 
model and all possible observations to estimate the coefficients of the lead and lag dummies. ${ }^{37}$

The results of our analyses for murder, rape, and robbery, together with Black and Nagin's estimates, are reported in Table 6. For murder and rape, the preadoption trends are similar: for both crimes, the lead dummies are not significantly different from each other, although the estimates suggest that the number of murders seems to have peaked 3 years before adoption of right-to-carry laws, while the trend for rapes was slightly increasing. The estimates for robbery, on the other hand, indicate the presence of a trend that had peaked 2 years before the adoption of the laws. ${ }^{38}$

For none of the categories is the dummy for the year 0 (the year during which right-to-carry laws were adopted) significantly different from that of the preceding year. That is not surprising if the laws were adopted in the middle of the year, so that any effect of such laws would not have affected crime rates for the whole year. There is often a delay of 2-3 months between the adoption of the law and the time when the first permits are issued, which might also explain why the year 0 coefficient is not statistically significant. ${ }^{39}$ In addition, the estimates suggest that it took about 1 year until criminals had learned that committing a crime had become more costly, because for the first year after implementation of the law only the estimate for rape is (barely) significantly below that of the preceding year. However, for all three crime categories the levels in years 2 and 3 after adoption of a right-to-carry law are significantly below the levels in the years before the adoption of the law, which suggests that there is generally a deterrent effect and that it takes about 1 year for this effect to emerge. ${ }^{40}$

\footnotetext{
${ }^{37}$ If a dependent variable is normally distributed, a model that is expressed in first differences is normal as well, because the difference of two normally distributed random variables is also normally distributed. The difference between two Poisson-lognormally distributed variables, however, is not Poisson-lognormally distributed but follows an unbounded discrete distribution whose closed-form solution is not known and which is difficult to approximate. Instead of expressing the regression equation in first differences, we therefore continued to use the number of crimes in a category as the dependent variables, and we undertook the analysis with county dummies, yearly dummies, and the independent nondummy variables that are described in Table 3.

${ }^{38}$ Note that it is irrelevant whether the estimates are significantly different from zero; what is relevant is whether the dummies for years after the adoption of right-to-carry laws are significantly different from the dummies before the adoption of such laws.

${ }^{39}$ John Lott, e-mail correspondence with the authors, November 19, 1999.

${ }^{40}$ Among the 10 states that adopted right-to-carry laws between 1977 and 1992, Maine was the only state that adopted such a law before 1987, which implies that the estimates of the coefficients of the lags for years 4 and 5 are obtained from data of a single state only. The standard errors of estimate of these coefficients are therefore much larger than the standard errors for the other years, and it is difficult to interpret these estimates together with the other estimates.
} 
TABLE 6

Intertemporal Impacts of Right-To-Carry LaWs on MuRder, RaPe, and Robbery

\begin{tabular}{|c|c|c|c|c|c|c|}
\hline & \multicolumn{2}{|c|}{ MuRder } & \multicolumn{2}{|c|}{ RAPE } & \multicolumn{2}{|c|}{ ROBBERY } \\
\hline & $\begin{array}{c}\text { Least-Squares } \\
\text { Estimates by } \\
\text { Black and Nagin }\end{array}$ & $\begin{array}{l}\text { Poisson-Lognormal } \\
\text { Estimates }^{\mathrm{b}}\end{array}$ & $\begin{array}{l}\text { Least-Squares } \\
\text { Estimates by } \\
\text { Black and Nagin }{ }^{\mathrm{a}}\end{array}$ & $\begin{array}{l}\text { Poisson-Lognormal } \\
\text { Estimates }^{\mathrm{b}}\end{array}$ & $\begin{array}{l}\text { Least-Squares } \\
\text { Estimates by } \\
\text { Black and Nagin }\end{array}$ & $\begin{array}{c}\text { Poisson-Lognormal } \\
\text { Estimates }^{\mathrm{b}}\end{array}$ \\
\hline $\begin{array}{l}\text { Years before the adoption of } \\
\text { right-to-carry laws: }\end{array}$ & & & & & & \\
\hline 5 & & $\begin{array}{l}.0313 \\
(.0192)\end{array}$ & & $\begin{array}{l}-.0260 \\
(.00939)\end{array}$ & & $\begin{array}{l}.1036 \\
(.00422)\end{array}$ \\
\hline 4 & $\begin{array}{l}-.015 \\
(.0454)\end{array}$ & $\begin{array}{l}.0393 \\
(.0193)\end{array}$ & $\begin{array}{r}-.057 * \\
(.0268)\end{array}$ & $\begin{array}{c}-.0388 \\
(.00929)\end{array}$ & $\begin{array}{l}.023 \\
(.0324)\end{array}$ & $\begin{array}{l}.1276 \\
(.00397)\end{array}$ \\
\hline 3 & $\begin{array}{l}-.039 \\
(.0609)\end{array}$ & $\begin{array}{l}.0474 \\
(.0189)\end{array}$ & $\begin{array}{l}-.073 \\
(.0394)\end{array}$ & $\begin{array}{l}-.0499 \\
(.00923)\end{array}$ & $\begin{array}{l}-.002 \\
(.0333)\end{array}$ & $\begin{array}{l}.1708 \\
(.00380)\end{array}$ \\
\hline 2 & $\begin{array}{l}.018 \\
(.0667)\end{array}$ & $\begin{array}{l}.0270 \\
(.0189)\end{array}$ & $\begin{array}{c}-.067 \\
(.0364)\end{array}$ & $\begin{array}{c}-.0455 \\
(.00912)\end{array}$ & $\begin{array}{l}.062 \\
(.0437)\end{array}$ & $\begin{array}{l}.2147 \\
(.00375)\end{array}$ \\
\hline 1 & $\begin{array}{l}-.094 \\
(.0718)\end{array}$ & $\begin{array}{l}.0160 \\
(.0226)\end{array}$ & $\begin{array}{l}-.095^{*} \\
(.0411)\end{array}$ & $\begin{array}{c}-.0174 \\
(.0110)\end{array}$ & $\begin{array}{l}.039 \\
(.0429)\end{array}$ & $\begin{array}{l}.1369 \\
(.00510)\end{array}$ \\
\hline
\end{tabular}




\begin{tabular}{|c|c|c|c|c|c|c|}
\hline 0 & $\begin{array}{c}-.022 \\
(.0759)\end{array}$ & $\begin{array}{c}.0068 \\
(.0185)\end{array}$ & $\begin{array}{l}-.053 \\
(.0351)\end{array}$ & $\begin{array}{c}-.0552 \\
(.00904)\end{array}$ & $\begin{array}{l}.096^{*} \\
(.0374)\end{array}$ & $\begin{array}{l}.1880 \\
(.00373)\end{array}$ \\
\hline 1 & $\begin{array}{l}-.089 \\
(.0659)\end{array}$ & $\begin{array}{c}-.0367 \\
(.0181)\end{array}$ & $\begin{array}{l}-.053 \\
(.0331)\end{array}$ & $\begin{array}{c}-.0979 \\
(.00899)\end{array}$ & $\begin{array}{l}.048 \\
(.0361)\end{array}$ & $\begin{array}{l}.1558 \\
(.00354)\end{array}$ \\
\hline 2 & $\begin{array}{l}.076 \\
.0905)\end{array}$ & $\begin{array}{c}-.1452 \\
(.0188)\end{array}$ & $\begin{array}{c}-.038 \\
(.0400)\end{array}$ & $\begin{array}{c}-.1088 \\
(.00910)\end{array}$ & $\begin{array}{c}.030 \\
-.032 \\
(.0457)\end{array}$ & $\begin{array}{l}.00888 \\
.09855) \\
(.00355)\end{array}$ \\
\hline 3 & $\begin{array}{c}-.088 \\
(.0740)\end{array}$ & $\begin{array}{r}-.0976 \\
(.0217)\end{array}$ & $\begin{array}{c}-.087^{*} \\
(.0412)\end{array}$ & $\begin{array}{c}-.1003 \\
(.0103)\end{array}$ & $\begin{array}{c}.029 \\
(.0433)\end{array}$ & $\begin{array}{l}.0569 \\
(.00405)\end{array}$ \\
\hline 4 & $\begin{array}{l}.080 \\
(.0792)\end{array}$ & $\begin{array}{l}.0668 \\
(.0436)\end{array}$ & $\begin{array}{c}-.066 \\
(.0367)\end{array}$ & $\begin{array}{c}-.0287 \\
(.0229)\end{array}$ & $\begin{array}{l}.040 \\
(.0408)\end{array}$ & $\begin{array}{l}.1437 \\
(.0113)\end{array}$ \\
\hline 5 & $\begin{array}{c}-.133 \\
(.0801)\end{array}$ & $\begin{array}{c}-.4125 \\
(.1332)\end{array}$ & $\begin{array}{c}-.123^{*} \\
(.0447)\end{array}$ & $\begin{array}{c}-.0216 \\
(.0418)\end{array}$ & $\begin{array}{c}-.018 \\
(.0462)\end{array}$ & $\begin{array}{c}-.2727 \\
(.0378)\end{array}$ \\
\hline & 5,449 & 44,614 & 5,587 & 45,450 & 5,725 & 45,952 \\
\hline
\end{tabular}

Note. - Estimated standard errors are shown in parentheses.

${ }^{a}$ Variables measured as differences. Dan A. Black \& Daniel S. Nagin, Do Right-to-Carry Laws Deter Violent Crime? 27 J. Legal Stud. 209 (1998).

Variable measured as levels.

* $\quad$ Significant at the $95 \%$ level, two-tailed tests, as reported by Black and Nagin. 


\section{Combination of the Intertemporal and the Geographical Models}

The results of the two preceding subsections indicate that there is enough geographical as well as intertemporal variation in the effects of the right to carry concealed handguns that an analysis requires a model that introduces both forms of variation simultaneously. We attempted to estimate state-specific lead and lag dummies but discovered that there are not enough data to estimate 11 dummies per state with adequate precision. We therefore decided to estimate a single pattern of lead and lag dummies and to include two additional dummies per state for nine of the 10 states to describe state-specific exponentially additive factors for the lead and lag dummies, using the following regression equation:

$$
\begin{aligned}
\mu_{c t}=\mathrm{POP}_{c t} \exp \left[\alpha_{s}+\sum_{r=-5}^{-1}\left(\beta_{\tau}+\delta_{1 s}\right) \mathrm{RTCD}_{c t \tau}\right. \\
\\
\left.+\sum_{r=0}^{3}\left(\beta_{\tau}+\delta_{2 s}\right) \mathrm{RTCD}_{c t \tau}+\gamma_{s} X_{c t}+\mathrm{YD}_{t}+\mathrm{CD}_{c}\right]
\end{aligned}
$$

where $\delta_{1 s}$ and $\delta_{2 s}$ are the two dummy variables for state $s^{41}$

The results of our analyses of murders, rapes, and robberies are reported in Tables 7, 8, and 9, respectively. For each state, the tables show estimates of the coefficients of the lead and lag dummies as well as the estimates of the coefficients of the two dummy variables for every state except Florida. For Florida, the reported leads and lags are the original estimates (and no dummies for the pre- and postlaw periods were estimated); for every other state, the reported leads and lags are calculated as the sum of the estimate for Florida and the dummy for that state for the respective period. The first two columns in each table summarize the information by showing the averages of the 5 years before right-to-carry laws were adopted and the averages for the first 4 years during which right-to-carry laws were effective.

Florida, Oregon, and Montana are the only states with statistically significant decreases in the averages of the coefficients for all three crime categories; Georgia also had significant decreases in murders and robberies, but the decrease in the number of rapes is not statistically significant. For Idaho, the estimates indicate statistically significant decreases of murders and robberies, but the estimated effect on rapes is statistically significantly positive. For West Virginia, the change in rapes is significantly negative; for Mississippi, the changes in rapes and robberies are positive and statistically significant; and for Virginia, the change in robberies is significantly positive.

\footnotetext{
${ }^{41}$ We included only three lags because Maine is the only state for which data for more than three lags are available.
} 
TABLE 7

Intertemporal and Geographical Impacts of Right-to-Carry LaWs on Murder

\begin{tabular}{|c|c|c|c|c|c|c|c|c|c|c|c|c|c|}
\hline & \multirow{2}{*}{$\begin{array}{l}\text { AVERAGE } \\
\text { BEFORE } \\
\text { ADOPTION }\end{array}$} & \multirow{2}{*}{$\begin{array}{l}\text { AvERAGE } \\
\text { AFTER } \\
\text { ADOPTION }\end{array}$} & \multirow{2}{*}{$\begin{array}{c}\text { DUMMY } \\
\text { BEFORE } \\
\text { ADOPTION }\end{array}$} & \multirow{2}{*}{$\begin{array}{c}\text { DUMMY } \\
\text { AFTER } \\
\text { ADOPTION }\end{array}$} & \multicolumn{5}{|c|}{$\begin{array}{l}\text { YeARS BEFORE AdOPTION OF } \\
\text { RIGHT-TO-CARRY LaWs }\end{array}$} & \multicolumn{4}{|c|}{$\begin{array}{l}\text { Years after AdOPTION OF } \\
\text { Right-TO-CARRY LaWs }\end{array}$} \\
\hline & & & & & 5 & 4 & 3 & 2 & 1 & 0 & 1 & 2 & 3 \\
\hline Florida $^{a}$ & $\begin{array}{l}.1212 \\
(.0250)\end{array}$ & $\begin{array}{l}-.1625 \\
(.0232)\end{array}$ & $\ldots$ & . & $\begin{array}{l}.1119 \\
(.0244)\end{array}$ & $\begin{array}{l}.1170 \\
(.0239)\end{array}$ & $\begin{array}{l}.1249 \\
(.0232)\end{array}$ & $\begin{array}{l}.1066 \\
(.0233)\end{array}$ & $\begin{array}{l}.1458 \\
(.0297)\end{array}$ & $\begin{aligned}-.0764 \\
(.0232)\end{aligned}$ & $\begin{array}{r}-.1222 \\
(.0232)\end{array}$ & $\begin{array}{c}-.2381 \\
(.0230)\end{array}$ & $\begin{array}{r}-.2134 \\
(.0250)\end{array}$ \\
\hline Georgia $^{a}$ & $\begin{array}{c}-.0021 \\
(.0380)\end{array}$ & $\begin{array}{c}-.1296 \\
(.0371)\end{array}$ & $\begin{array}{c}-.1233 \\
(.0286)\end{array}$ & $\begin{array}{l}.0329 \\
(.0309)\end{array}$ & $\begin{array}{c}-.0114 \\
(.0377)\end{array}$ & $\begin{array}{c}-.0063 \\
(.0373)\end{array}$ & $\begin{array}{c}.0016 \\
(.0369)\end{array}$ & $\begin{array}{c}-.0167 \\
(.0369)\end{array}$ & $\begin{array}{l}.0225 \\
(.0413)\end{array}$ & $\begin{array}{c}-.0435 \\
(.0369)\end{array}$ & $\begin{array}{c}-.0892 \\
(.0369)\end{array}$ & $\begin{array}{c}-.2052 \\
(.0367)\end{array}$ & $\begin{array}{c}-.1804 \\
(.0380)\end{array}$ \\
\hline Idaho $^{a}$ & $\begin{array}{l}-.1800 \\
(.1056)\end{array}$ & $\begin{array}{l}-.4241 \\
(.1053)\end{array}$ & $\begin{array}{c}-.3012 \\
(.1026)\end{array}$ & $\begin{array}{l}-.2616 \\
(.1257)\end{array}$ & $\begin{array}{c}-.1894 \\
(.1055)\end{array}$ & $\begin{array}{c}-.1842 \\
(.1054)\end{array}$ & $\begin{array}{c}-.1764 \\
(.1052)\end{array}$ & $\begin{array}{r}-.1946 \\
(.1052)\end{array}$ & $\begin{array}{c}-.1554 \\
(.1068)\end{array}$ & $\begin{array}{l}-.3381 \\
(.1052)\end{array}$ & $\begin{array}{r}-.3838 \\
(.1052)\end{array}$ & $\begin{array}{r}-.4997 \\
(.1052)\end{array}$ & $\begin{array}{r}-.4750 \\
(.1056)\end{array}$ \\
\hline Maine & $\begin{array}{l}-.0412 \\
(.1421)\end{array}$ & $\begin{array}{l}.1081 \\
(.1419)\end{array}$ & $\begin{array}{l}-.1625 \\
(.1399)\end{array}$ & $\begin{array}{l}.2706 \\
(.1378)\end{array}$ & $\begin{array}{l}-.0506 \\
(.1420)\end{array}$ & $\begin{array}{r}-.0454 \\
(.1419)\end{array}$ & $\begin{array}{r}-.0376 \\
(.1418)\end{array}$ & $\begin{array}{r}-.0559 \\
(.1418)\end{array}$ & $\begin{array}{r}-.0167 \\
(.1430)\end{array}$ & $\begin{array}{l}.1942 \\
(.1418)\end{array}$ & $\begin{array}{l}.1484 \\
(.1418)\end{array}$ & $\begin{array}{l}.0325 \\
(.1418)\end{array}$ & $\begin{array}{l}.0572 \\
(.1421)\end{array}$ \\
\hline Mississippi & $\begin{array}{c}-.1542 \\
(.0558)\end{array}$ & $\begin{array}{c}-.1159 \\
(.0552)\end{array}$ & $\begin{array}{c}-.2754 \\
(.0499)\end{array}$ & $\begin{array}{l}.0466 \\
(.0547)\end{array}$ & $\begin{array}{c}-.1636 \\
(.0556)\end{array}$ & $\begin{array}{r}-.1584 \\
(.0553)\end{array}$ & $\begin{array}{c}-.1506 \\
(.0551)\end{array}$ & $\begin{array}{c}-.1688 \\
(.0551)\end{array}$ & $\begin{array}{c}-.1296 \\
(.0581)\end{array}$ & $\begin{array}{c}-.0298 \\
(.0551)\end{array}$ & $\begin{array}{c}-.0756 \\
(.0551)\end{array}$ & $\begin{array}{c}-.1915 \\
(.0550)\end{array}$ & $\begin{array}{c}-.1667 \\
(.0558)\end{array}$ \\
\hline Mon & $\begin{array}{l}-.1722 \\
(.1171)\end{array}$ & $\begin{array}{l}-.8058 \\
(.1168)\end{array}$ & $\begin{array}{l}-.2934 \\
(.1144)\end{array}$ & $\begin{array}{l}-.6432 \\
(.1894)\end{array}$ & $\begin{array}{c}-.1816 \\
(.1169)\end{array}$ & $\begin{array}{c}-.1764 \\
(.1168)\end{array}$ & $\begin{array}{c}-.1686 \\
(.1167)\end{array}$ & $\begin{array}{r}-.1869 \\
(.1167)\end{array}$ & $\begin{array}{c}-.1476 \\
(.1182)\end{array}$ & $\begin{array}{c}-.7197 \\
(.1167)\end{array}$ & $\begin{array}{c}-.7654 \\
(.1167)\end{array}$ & $\begin{array}{c}-.8814 \\
(.1167)\end{array}$ & $\begin{array}{r}-.8566 \\
(.1171)\end{array}$ \\
\hline Oregon $^{\mathrm{a}}$ & $\begin{array}{l}.2755 \\
(.0574)\end{array}$ & $\begin{array}{c}-.0832 \\
(.0568)\end{array}$ & $\begin{array}{l}.1543 \\
(.0517)\end{array}$ & $\begin{array}{l}.0793 \\
(.0630)\end{array}$ & $\begin{array}{l}.2662 \\
(.0572)\end{array}$ & $\begin{array}{l}.2713 \\
(.0569)\end{array}$ & $\begin{array}{c}.2792 \\
(.0567)\end{array}$ & $\begin{array}{l}.2609 \\
(.0567)\end{array}$ & $\begin{array}{l}.3001 \\
(.0596)\end{array}$ & $\begin{array}{c}.0029 \\
(.0566)\end{array}$ & $\begin{array}{r}-.0429 \\
(.0567)\end{array}$ & $\begin{array}{r}-.1588 \\
(.0566)\end{array}$ & $\begin{array}{r}-.1340 \\
(.0574)\end{array}$ \\
\hline Pennsylvania & $\begin{array}{l}.0033 \\
(.0388)\end{array}$ & $\begin{array}{l}.0703 \\
(.0379)\end{array}$ & $\begin{array}{c}-.1180 \\
(.0297)\end{array}$ & $\begin{array}{l}.2328 \\
(.0295)\end{array}$ & $\begin{array}{c}-.0061 \\
(.0384)\end{array}$ & $\begin{array}{c}-.0009 \\
(.0381)\end{array}$ & $\begin{array}{c}.0069 \\
(.0377)\end{array}$ & $\begin{array}{c}-.0114 \\
(.0377)\end{array}$ & $\begin{array}{l}.0279 \\
(.0420)\end{array}$ & $\begin{array}{l}.1564 \\
(.0377)\end{array}$ & $\begin{array}{l}.1106 \\
(.0377)\end{array}$ & $\begin{array}{c}-.0053 \\
(.0375)\end{array}$ & $\begin{array}{c}.0194 \\
(.0388)\end{array}$ \\
\hline Virginia & $\begin{array}{l}.0240 \\
(.0435)\end{array}$ & $\begin{array}{l}.0854 \\
(.0427)\end{array}$ & $\begin{array}{c}-.0973 \\
(.0356)\end{array}$ & $\begin{array}{l}.2479 \\
(.0343)\end{array}$ & $\begin{array}{l}.0146 \\
(.0432)\end{array}$ & $\begin{array}{l}.0197 \\
(.0429)\end{array}$ & $\begin{array}{l}.0276 \\
(.0425)\end{array}$ & $\begin{array}{l}.0093 \\
(.0425)\end{array}$ & $\begin{array}{l}.0485 \\
(.0463)\end{array}$ & $\begin{array}{l}.1715 \\
(.0425)\end{array}$ & $\begin{array}{l}.1258 \\
(.0425)\end{array}$ & $\begin{array}{c}.0098 \\
(.0424)\end{array}$ & $\begin{array}{l}.0346 \\
(.0435)\end{array}$ \\
\hline West Virginia & $\begin{array}{c}-.0065 \\
(.0663)\end{array}$ & $\begin{array}{l}.1201 \\
(.0657)\end{array}$ & $\begin{array}{c}-.1278 \\
(.0614)\end{array}$ & $\begin{array}{l}.2827 \\
(.0603)\end{array}$ & $\begin{array}{c}-.0159 \\
(.0660)\end{array}$ & $\begin{array}{c}-.0107 \\
(.0658)\end{array}$ & $\begin{array}{c}-.0029 \\
(.0656)\end{array}$ & $\begin{array}{r}-.0212 \\
(.0656)\end{array}$ & $\begin{array}{l}.0180 \\
(.0682)\end{array}$ & $\begin{array}{c}.2062 \\
(.0656)\end{array}$ & $\begin{array}{l}.1605 \\
(.0656)\end{array}$ & $\begin{array}{l}.0445 \\
(.0655)\end{array}$ & $\begin{array}{l}.0693 \\
(.0663)\end{array}$ \\
\hline
\end{tabular}

Note. - Estimated standard errors are shown in parentheses.

${ }^{a}$ Significant decrease between the two averages (statistically significant at the $95 \%$ confidence level). 
TABLE 8

INTERTEMPORAL AND GEOGRAPHICAL IMPACTS OF RighT-TO-CARRY LAWS ON RAPE

\begin{tabular}{|c|c|c|c|c|c|c|c|c|c|c|c|c|c|}
\hline & \multirow{2}{*}{$\begin{array}{l}\text { AVERAGE } \\
\text { BEFORE } \\
\text { ADOPTION }\end{array}$} & \multirow{2}{*}{$\begin{array}{l}\text { AvERAGE } \\
\text { AFTER } \\
\text { ADOPTION }\end{array}$} & \multirow{2}{*}{$\begin{array}{c}\text { DUMMY } \\
\text { BEFORE } \\
\text { ADOPTION }\end{array}$} & \multirow{2}{*}{$\begin{array}{c}\text { DUMMY } \\
\text { AFTER } \\
\text { ADOPTION }\end{array}$} & \multicolumn{5}{|c|}{$\begin{array}{c}\text { YeARS BEFORE AdOPTION OF } \\
\text { RIGHT-TO-CARRY LAWS }\end{array}$} & \multicolumn{4}{|c|}{$\begin{array}{c}\text { Years aFter Adoption of } \\
\text { Right-TO-CARRY LaWs }\end{array}$} \\
\hline & & & & & 5 & 4 & 3 & 2 & 1 & 0 & 1 & 2 & 3 \\
\hline Florida ${ }^{a}$ & $\begin{array}{l}-.0617 \\
(.0121)\end{array}$ & $\begin{array}{c}-.1613 \\
(.0115)\end{array}$ & & . & $\begin{aligned}-.0545 \\
(.0118)\end{aligned}$ & $\begin{array}{r}-.0659 \\
(.0115)\end{array}$ & $\begin{array}{r}-.0760 \\
(.0113)\end{array}$ & $\begin{array}{c}-.0711 \\
(.0115)\end{array}$ & $\begin{array}{r}-.0409 \\
(.0142)\end{array}$ & $\begin{array}{c}-.1183 \\
(.0117)\end{array}$ & $\begin{array}{c}-.1593 \\
(.0116)\end{array}$ & $\begin{array}{c}-.1728 \\
(.0114)\end{array}$ & $\begin{aligned}-.1519 \\
(.0121)\end{aligned}$ \\
\hline Georgia & $\begin{array}{l}.0347 \\
(.0199)\end{array}$ & $\begin{array}{c}-.0173 \\
(.0197)\end{array}$ & $\begin{array}{c}.0963 \\
(.0159)\end{array}$ & $\begin{array}{l}.1333 \\
(.0178)\end{array}$ & $\begin{array}{l}.0418 \\
(.0198)\end{array}$ & $\begin{array}{c}.0305 \\
(.0196)\end{array}$ & $\begin{array}{c}.0204 \\
(.0195)\end{array}$ & $\begin{array}{c}.0253 \\
(.0196)\end{array}$ & $\begin{array}{c}.0555 \\
(.0213)\end{array}$ & $\begin{array}{l}.0150 \\
(.0197)\end{array}$ & $\begin{array}{c}-.0260 \\
(.0197)\end{array}$ & $\begin{array}{c}-.0395 \\
(.0195)\end{array}$ & $\begin{array}{r}-.0186 \\
(.0200)\end{array}$ \\
\hline Idaho $^{\mathrm{b}}$ & $\begin{array}{l}-.2225 \\
(.0458)\end{array}$ & $\begin{array}{l}-.0468 \\
(.0457)\end{array}$ & $\begin{array}{r}-.1609 \\
(.0442)\end{array}$ & $\begin{array}{l}.1038 \\
(.0439)\end{array}$ & $\begin{array}{r}-.2154 \\
(.0457)\end{array}$ & $\begin{array}{r}-.2268 \\
(.0457)\end{array}$ & $\begin{array}{r}-.2369 \\
(.0456)\end{array}$ & $\begin{array}{r}-.2320 \\
(.0457)\end{array}$ & $\begin{array}{r}-.2017 \\
(.0464)\end{array}$ & $\begin{array}{c}-.0145 \\
(.0457)\end{array}$ & $\begin{array}{c}-.0555 \\
(.0457)\end{array}$ & $\begin{array}{r}-.0690 \\
(.0456)\end{array}$ & $\begin{array}{r}-.0481 \\
(.0458)\end{array}$ \\
\hline Maine & $\begin{array}{c}-.0489 \\
(.0647)\end{array}$ & $\begin{array}{c}-.1108 \\
(.0646)\end{array}$ & $\begin{array}{l}.0128 \\
(.0636)\end{array}$ & $\begin{array}{l}.0398 \\
(.0618)\end{array}$ & $\begin{array}{r}-.0417 \\
(.0646)\end{array}$ & $\begin{aligned}-.0531 \\
(.0646)\end{aligned}$ & $\begin{array}{r}-.0632 \\
(.0645)\end{array}$ & $\begin{array}{c}-.0583 \\
(.0646)\end{array}$ & $\begin{array}{c}-.0281 \\
(.0651)\end{array}$ & $\begin{array}{l}-.0785 \\
(.0646)\end{array}$ & $\begin{array}{l}-.1195 \\
(.0646)\end{array}$ & $\begin{array}{r}-.1330 \\
(.0646)\end{array}$ & $\begin{aligned}-.1121 \\
(.0647)\end{aligned}$ \\
\hline Mississippi $^{\mathrm{b}}$ & $\begin{array}{r}-.1111 \\
(.0320)\end{array}$ & $\begin{array}{l}.0630 \\
(.0318)\end{array}$ & $\begin{array}{r}-.0495 \\
(.0296)\end{array}$ & $\begin{array}{l}.2136 \\
(.0315)\end{array}$ & $\begin{array}{r}-.1039 \\
(.0319)\end{array}$ & $\begin{array}{r}-.1153 \\
(.0318)\end{array}$ & $\begin{array}{r}-.1254 \\
(.0317)\end{array}$ & $\begin{array}{r}-.1205 \\
(.0317)\end{array}$ & $\begin{array}{c}-.0903 \\
(.0328)\end{array}$ & $\begin{array}{l}.0953 \\
(.0318)\end{array}$ & $\begin{array}{l}.0543 \\
(.0318)\end{array}$ & $\begin{array}{l}.0408 \\
(.0317)\end{array}$ & $\begin{array}{l}.0617 \\
(.0320)\end{array}$ \\
\hline Montana $^{\mathrm{a}}$ & $\begin{array}{c}-.3064 \\
(.0509)\end{array}$ & $\begin{array}{c}-.5223 \\
(.0508)\end{array}$ & $\begin{array}{c}-.2447 \\
(.0495)\end{array}$ & $\begin{array}{c}-.3717 \\
(.0679)\end{array}$ & $\begin{array}{r}-.2992 \\
(.0509)\end{array}$ & $\begin{array}{c}-.3106 \\
(.0508)\end{array}$ & $\begin{array}{c}-.3207 \\
(.0508)\end{array}$ & $\begin{array}{c}-.3158 \\
(.0508)\end{array}$ & $\begin{array}{c}-.2856 \\
(.0515)\end{array}$ & $\begin{array}{c}-.4900 \\
(.0508)\end{array}$ & $\begin{array}{c}-.5310 \\
(.0508)\end{array}$ & $\begin{array}{c}-.5445 \\
(.0508)\end{array}$ & $\begin{array}{r}-.5236 \\
(.0509)\end{array}$ \\
\hline Oregon & $\begin{array}{l}.0040 \\
(.0228)\end{array}$ & $\begin{array}{c}-.0647 \\
(.0226)\end{array}$ & $\begin{array}{l}.0657 \\
(.0193)\end{array}$ & $\begin{array}{c}.0858 \\
(.0215)\end{array}$ & $\begin{array}{l}.0112 \\
(.0226)\end{array}$ & $\begin{array}{r}-.0002 \\
(.0225)\end{array}$ & $\begin{array}{c}-.0103 \\
(.0224)\end{array}$ & $\begin{array}{c}-.0054 \\
(.0225)\end{array}$ & $\begin{array}{l}.0248 \\
(.0239)\end{array}$ & $\begin{array}{c}-.0325 \\
(.0226)\end{array}$ & $\begin{array}{c}-.0735 \\
(.0225)\end{array}$ & $\begin{array}{c}-.0869 \\
(.0224)\end{array}$ & $\begin{array}{r}-.0660 \\
(.0228)\end{array}$ \\
\hline Pennsylvania & $\begin{array}{l}.0134 \\
(.0189)\end{array}$ & $\begin{array}{r}-.0360 \\
(.0186)\end{array}$ & $\begin{array}{l}.0750 \\
(.0145)\end{array}$ & $\begin{array}{l}.1145 \\
(.0149)\end{array}$ & $\begin{array}{l}.0205 \\
(.0187)\end{array}$ & $\begin{array}{l}.0091 \\
(.0185)\end{array}$ & $\begin{array}{r}-.0010 \\
(.0183)\end{array}$ & $\begin{array}{l}.0040 \\
(.0185)\end{array}$ & $\begin{array}{l}.0342 \\
(.0202)\end{array}$ & $\begin{array}{r}-.0038 \\
(.0186)\end{array}$ & $\begin{array}{r}-.0447 \\
(.0186)\end{array}$ & $\begin{array}{r}-.0582 \\
(.0184)\end{array}$ & $\begin{array}{r}-.0373 \\
(.0189)\end{array}$ \\
\hline Virginia & $\begin{array}{c}-.0800 \\
(.0220)\end{array}$ & $\begin{array}{c}-.0601 \\
(.0218)\end{array}$ & $\begin{array}{c}-.0184 \\
(.0184)\end{array}$ & $\begin{array}{c}.0905 \\
(.0192)\end{array}$ & $\begin{array}{c}-.0728 \\
(.0218)\end{array}$ & $\begin{array}{r}-.0842 \\
(.0217)\end{array}$ & $\begin{array}{c}-.0943 \\
(.0215)\end{array}$ & $\begin{array}{c}-.0894 \\
(.0217)\end{array}$ & $\begin{array}{c}-.0592 \\
(.0232)\end{array}$ & $\begin{array}{c}-.0279 \\
(.0217)\end{array}$ & $\begin{array}{c}-.0688 \\
(.0217)\end{array}$ & $\begin{array}{c}-.0823 \\
(.0216)\end{array}$ & $\begin{array}{c}-.0614 \\
(.0220)\end{array}$ \\
\hline West Virginia $^{a}$ & $\begin{array}{c}-.0350 \\
(.0365)\end{array}$ & $\begin{array}{c}-.2152 \\
(.0363)\end{array}$ & $\begin{array}{c}.0266 \\
(.0344)\end{array}$ & $\begin{array}{c}-.0646 \\
(.0353)\end{array}$ & $\begin{array}{r}-.0279 \\
(.0364)\end{array}$ & $\begin{array}{r}-.0393 \\
(.0363)\end{array}$ & $\begin{array}{c}-.0494 \\
(.0362)\end{array}$ & $\begin{array}{c}-.0445 \\
(.0363)\end{array}$ & $\begin{array}{c}-.0142 \\
(.0372)\end{array}$ & $\begin{array}{c}-.1830 \\
(.0363)\end{array}$ & $\begin{array}{c}-.2239 \\
(.0363)\end{array}$ & $\begin{array}{c}-.2374 \\
(.0363)\end{array}$ & $\begin{array}{r}-.2165 \\
(.0365)\end{array}$ \\
\hline
\end{tabular}

NoTE. - Estimated standard errors are shown in parentheses.

${ }^{a}$ Significant decrease between the two averages (statistically significant at the $95 \%$ confidence level).

${ }^{b}$ Significant increase between the two averages (statistically significant at the $95 \%$ confidence level). 
TABLE 9

INTERTEMPORAL AND GEOGRAPHICAL IMPACTS OF Right-TO-CARRY LAWS ON ROBbeRY

\begin{tabular}{|c|c|c|c|c|c|c|c|c|c|c|c|c|c|}
\hline & \multirow{2}{*}{$\begin{array}{l}\text { AVERAGE } \\
\text { BEFORE } \\
\text { ADOPTION }\end{array}$} & \multirow{2}{*}{$\begin{array}{l}\text { AVERAGE } \\
\text { AFTER } \\
\text { ADOPTION }\end{array}$} & \multirow{2}{*}{$\begin{array}{c}\text { DUMMY } \\
\text { BEFORE } \\
\text { ADOPTION }\end{array}$} & \multirow{2}{*}{$\begin{array}{l}\text { DUMMY } \\
\text { AFTER } \\
\text { ADOPTION }\end{array}$} & \multicolumn{5}{|c|}{$\begin{array}{l}\text { YeARS BEFORE AdOPTION OF } \\
\text { RIGHT-TO-CARRY LAWS }\end{array}$} & \multicolumn{4}{|c|}{$\begin{array}{l}\text { Years AFter AdOPTION OF } \\
\text { RigHT-TO-CARRY LAWS }\end{array}$} \\
\hline & & & & & 5 & 4 & 3 & 2 & 1 & 0 & 1 & 2 & 3 \\
\hline Florida $^{a}$ & $\begin{array}{l}.2616 \\
(.0051)\end{array}$ & $\begin{array}{l}.2335 \\
(.0043)\end{array}$ & $\ldots$ & $\ldots$ & $\begin{array}{l}.2085 \\
(.0050)\end{array}$ & $\begin{array}{l}.2318 \\
(.0047)\end{array}$ & $\begin{array}{l}.2763 \\
(.0045)\end{array}$ & $\begin{array}{l}.3197 \\
(.0045)\end{array}$ & $\begin{array}{l}.2715 \\
(.0063)\end{array}$ & $\begin{array}{l}.3027 \\
(.0044)\end{array}$ & $\begin{array}{l}.2675 \\
(.0043)\end{array}$ & $\begin{array}{c}.2077 \\
(.0042)\end{array}$ & $\begin{array}{l}.1562 \\
(.0045)\end{array}$ \\
\hline Georgia $^{a}$ & $\begin{array}{c}.3083 \\
(.0083)\end{array}$ & $\begin{array}{c}.2553 \\
.0079)\end{array}$ & $\begin{array}{c}.0468 \\
(.0066)\end{array}$ & $\begin{array}{c}.0218 \\
(.0068)\end{array}$ & $\begin{array}{l}.2553 \\
(.0083)\end{array}$ & $\begin{array}{l}.2786 \\
.0081)\end{array}$ & $\begin{array}{c}.3231 \\
.0080)\end{array}$ & $\begin{array}{l}.3665 \\
(.0080)\end{array}$ & $\begin{array}{c}.3183 \\
(.0091)\end{array}$ & $\begin{array}{c}.3245 \\
(.0080)\end{array}$ & $\begin{array}{c}.2893 \\
.0079)\end{array}$ & $\begin{array}{l}.2296 \\
.0079)\end{array}$ & $\begin{array}{r}.1780 \\
(.0080)\end{array}$ \\
\hline Idaho $^{\mathrm{a}}$ & $\begin{array}{c}-.5158 \\
(.0370)\end{array}$ & $\begin{array}{r}-.8319 \\
(.0369)\end{array}$ & $\begin{array}{c}-.7774 \\
(.0366)\end{array}$ & $\begin{array}{c}-1.0654 \\
(.0450)\end{array}$ & $\begin{array}{r}-.5689 \\
(.0369)\end{array}$ & $\begin{array}{l}-.5455 \\
(.0369)\end{array}$ & $\begin{array}{c}-.5011 \\
(.0369)\end{array}$ & $\begin{array}{c}-.4577 \\
(.0369)\end{array}$ & $\begin{array}{l}-.5059 \\
(.0371)\end{array}$ & $\begin{array}{l}-.7627 \\
(.0369)\end{array}$ & $\begin{array}{r}-.7979 \\
(.0369)\end{array}$ & $\begin{array}{c}-.8577 \\
(.0369)\end{array}$ & $\begin{array}{r}-.9092 \\
(.0369)\end{array}$ \\
\hline Maine & $\begin{aligned}-.2400 \\
(.0384)\end{aligned}$ & $\begin{array}{l}-.3607 \\
(.0384)\end{array}$ & $\begin{array}{l}-.5016 \\
(.0381)\end{array}$ & $\begin{array}{r}-.5942 \\
(.0390)\end{array}$ & $\begin{array}{l}-.2930 \\
(.0384)\end{array}$ & $\begin{array}{r}-.2697 \\
(.0384)\end{array}$ & $\begin{array}{r}-.2252 \\
(.0384)\end{array}$ & $\begin{array}{r}-.1819 \\
(.0384)\end{array}$ & $\begin{array}{c}-.2301 \\
(.0386)\end{array}$ & $\begin{array}{l}-.2915 \\
(.0384)\end{array}$ & $\begin{array}{l}-.3267 \\
(.0383)\end{array}$ & $\begin{array}{c}-.3864 \\
(.0383)\end{array}$ & $\begin{array}{r}-.4380 \\
(.0384)\end{array}$ \\
\hline Mississippi ${ }^{\mathrm{b}}$ & $\begin{array}{c}-.1499 \\
(.0188)\end{array}$ & $\begin{array}{l}.1433 \\
(.0187)\end{array}$ & $\begin{array}{l}-.4115 \\
(.0181)\end{array}$ & $\begin{array}{c}-.0902 \\
(.0183)\end{array}$ & $\begin{array}{l}-.2030 \\
(.0188)\end{array}$ & $\begin{array}{c}-.1797 \\
(.0187)\end{array}$ & $\begin{array}{c}-.1352 \\
(.0187)\end{array}$ & $\begin{array}{c}-.0918 \\
(.0187)\end{array}$ & $\begin{array}{l}-.1400 \\
(.0192)\end{array}$ & $\begin{array}{l}.2125 \\
(.0187)\end{array}$ & $\begin{array}{l}.1773 \\
(.0186)\end{array}$ & $\begin{array}{l}.1175 \\
(.0186)\end{array}$ & $\begin{array}{l}.0660 \\
(.0187)\end{array}$ \\
\hline Montana $^{a}$ & $\begin{array}{l}-.5237 \\
(.0434)\end{array}$ & $\begin{array}{l}-.7024 \\
(.0433)\end{array}$ & $\begin{array}{c}-.7852 \\
(.0431)\end{array}$ & $\begin{array}{c}-.9359 \\
(.0612)\end{array}$ & $\begin{array}{c}-.5767 \\
(.0434)\end{array}$ & $\begin{array}{c}-.5534 \\
(.0434)\end{array}$ & $\begin{array}{r}-.5089 \\
(.0433)\end{array}$ & $\begin{array}{c}-.4655 \\
(.0433)\end{array}$ & $\begin{array}{c}-.5137 \\
(.0436)\end{array}$ & $\begin{array}{c}-.6333 \\
(.0433)\end{array}$ & $\begin{array}{r}-.6685 \\
(.0433)\end{array}$ & $\begin{array}{c}-.7282 \\
(.0433)\end{array}$ & $\begin{array}{r}-.7798 \\
(.0433)\end{array}$ \\
\hline Oregor & $\begin{array}{c}.2228 \\
(.0106)\end{array}$ & $\begin{array}{c}-.2156 \\
(.0103)\end{array}$ & $\begin{array}{c}-.0388 \\
(.0093)\end{array}$ & $\begin{array}{c}-.4491 \\
(.0110)\end{array}$ & $\begin{array}{l}.1698 \\
(.0106)\end{array}$ & $\begin{array}{l}.1931 \\
(.0104)\end{array}$ & $\begin{array}{c}.2375 \\
(.0103)\end{array}$ & $\begin{array}{l}.2809 \\
. .0104)\end{array}$ & $\begin{array}{c}.2327 \\
(.0112)\end{array}$ & $\begin{array}{c}-.1464 \\
(.0103)\end{array}$ & $\begin{array}{r}-.1816 \\
(.0103)\end{array}$ & $\begin{array}{c}-.2413 \\
(.0102)\end{array}$ & $\begin{array}{r}-.2929 \\
(.0103)\end{array}$ \\
\hline Pennsylvania & $\begin{array}{c}-.0166 \\
(.0075)\end{array}$ & $\begin{array}{c}-.0072 \\
(.0071)\end{array}$ & $\begin{array}{c}-.2782 \\
(.0056)\end{array}$ & $\begin{array}{c}-.2407 \\
(.0055)\end{array}$ & $\begin{array}{c}-.0697 \\
(.0075)\end{array}$ & $\begin{array}{c}-.0464 \\
(.0073)\end{array}$ & $\begin{array}{c}-.0019 \\
(.0072)\end{array}$ & $\begin{array}{l}.0415 \\
(.0072)\end{array}$ & $\begin{array}{c}-.0067 \\
(.0084)\end{array}$ & $\begin{array}{l}.0620 \\
(.0071)\end{array}$ & $\begin{array}{l}.0267 \\
. .0070)\end{array}$ & $\begin{array}{c}-.0330 \\
(.0070)\end{array}$ & $\begin{array}{r}-.0845 \\
(.0072)\end{array}$ \\
\hline Virginia $^{c}$ & $\begin{array}{c}-.0298 \\
(.0099)\end{array}$ & $\begin{array}{l}.0034 \\
(.0096)\end{array}$ & $\begin{array}{c}-.2914 \\
(.0085)\end{array}$ & $\begin{array}{c}-.2301 \\
(.0085)\end{array}$ & $\begin{array}{c}-.0829 \\
(.0099)\end{array}$ & $\begin{array}{c}-.0596 \\
(.0098)\end{array}$ & $\begin{array}{c}-.0151 \\
(.0097)\end{array}$ & $\begin{array}{l}.0283 \\
(.0097)\end{array}$ & $\begin{array}{r}-.0199 \\
(.0106)\end{array}$ & $\begin{array}{l}.0726 \\
(.0096)\end{array}$ & $\begin{array}{l}.0374 \\
(.0096)\end{array}$ & $\begin{array}{c}-.0224 \\
(.0095)\end{array}$ & $\begin{array}{r}-.0739 \\
(.0097)\end{array}$ \\
\hline West Virginia & $\begin{array}{c}-.1290 \\
(.0220)\end{array}$ & $\begin{array}{c}-.1571 \\
(.0219)\end{array}$ & $\begin{array}{c}-.3906 \\
(.0214)\end{array}$ & $\begin{array}{c}-.3906 \\
(.0222)\end{array}$ & $\begin{array}{c}-.1820 \\
(.0220)\end{array}$ & $\begin{array}{c}-.1587 \\
(.0220)\end{array}$ & $\begin{array}{c}-.1143 \\
(.0219)\end{array}$ & $\begin{array}{c}-.0709 \\
(.0219)\end{array}$ & $\begin{array}{c}-.1191 \\
(.0224)\end{array}$ & $\begin{array}{c}-.0879 \\
(.0219)\end{array}$ & $\begin{array}{c}-.1232 \\
(.0219)\end{array}$ & $\begin{array}{c}-.1829 \\
(.0219)\end{array}$ & $\begin{array}{r}-.2344 \\
(.0219)\end{array}$ \\
\hline
\end{tabular}

Note. - Estimated standard errors are shown in parentheses.

a Significant decrease between the two averages (statistically significant at the $95 \%$ confidence level).

Significant increase between the two averages (statistically significant at the $95 \%$ confidence level).
c Significant increase between the two averages (statistically significant at the $90 \%$ confidence level). 
Maine and Pennsylvania are the only states for which none of the estimates is statistically significantly different from zero.

Comparison of the results of this combined analysis with the earlier results provides some interesting insights. The estimates in Table 7 for Florida, Idaho, Mississippi, and Montana have identical signs and the same degrees of statistical significance as the estimates in the combined analysis. For Maine, Oregon, and West Virginia, the estimated effects have identical signs in both analyses, although the degrees of significance vary. For Georgia and Virginia, the two analyses suggest different effects for robbery. For Pennsylvania, the analysis reported in Table 5 yielded significant effects for rape and robbery, while in the combined analysis, none of the effects is significantly different from zero, and the signs of the effects on all three crimes are reversed. This indicates that a model that describes only geographical variation will work quite well on average for these data but that its estimates will still not be completely reliable. Unlike the intertemporal analysis in Table 6, the combined analysis indicates that the numbers of murders and rapes had already changed significantly in the year during which a right-to-carry law was adopted and that the number of robberies changed in the first year after adoption. The combined analysis also shows that the deterrent effect of rightto-carry laws on murder and rape does not peak in the second year after adoption but that the effect increases even in the third year. This indicates that an intertemporal analysis that ignores geographical variation is subject to the same geographical aggregation bias as an analysis that estimates the effect of right-to-carry laws with a single dummy variable.

\section{Summary and Conclusion}

In this paper, we use a Poisson-lognormal model to analyze intertemporal and geographical variations in the effects of right-to-carry laws on murders, rapes, and robberies. For each of these crime categories, our estimates suggest the existence of statistically significant deterrent effects of right-to-carry laws for the majority of the 10 states that have adopted such laws between 1977 and 1992, but we also find that some of these states experienced statistically significant increases in the numbers of certain crimes.

On the one hand, this indicates that right-to-carry laws do not always have the deterrent effects on crime that are envisaged by legislators and that the adoption of such laws is not without risk. On the other hand, our analysis suggests that it would be imprudent to make it generally more difficult for law-abiding citizens to carry concealed handguns as long as there exist large numbers of weapons that can and will be used by criminals to commit crimes, because right-to-carry laws do help on average to reduce the number of these crimes.

While this ambiguous result is somewhat discouraging, because it indicates that a right to carry concealed handguns is unlikely to be the ultimate weapon 
against crime, it is not very surprising. Whenever the theoretically possible and in-practice plausible effects of public policy are ambiguous, it can be expected that the effects of such a policy will differ across localities that are different from each other. It is rather remarkable that these effects differ so clearly and that our analysis produced so many statistically significant and consistent results.

After having found that right-to-carry laws do have measurable effects on crimes, the next step is to examine why states differ in their responses to these laws. What makes Mississippi and Virginia, two states with general increases in crime rates, so different from the other states? In what respect is Idaho, a state with significant decreases in murders and robberies but significant increases in the number of rapes, different from Florida, Montana, and Oregon, which experienced significant decreases in all three crime categories? Answers to these questions will enhance our understanding of why right-to-carry laws lead to fewer crimes in many but not all states and will make it easier to decide when the adoption of such laws should be recommended.

\section{BIBLIOGRAPHY}

Bartley, William Alan, and Cohen, Mark A. "The Effect of Concealed Weapon Laws: An Extreme Bound Analysis.” Economic Inquiry 36 (1998): 258-65.

Black, Dan A., and Nagin, Daniel S. "Do Right-to-Carry Laws Deter Violent Crime?" Journal of Legal Studies 27 (1998): 209-19.

Cameron, Adrian Colin, and Trivedi, Pravin K. Regression Analysis of Count Data. Cambridge: Cambridge University Press, 1999.

Casella, George, and George, Edward I. "Explaining the Gibbs Sampler." American Statistician 46 (1992): 167-74.

Gelfand, Alan E., and Smith, Adrian F. M. "Sampling-Based Approaches to Calculating Marginal Densities." Journal of the American Statistical Association 85 (1990): 398-409.

Gilks, Walter R.; Richardson, Sylvia; and Spiegelhalter, David J. Markov Chain Monte Carlo in Practice. London: Chapman \& Hall, 1996.

Gourieroux, Christian; Monfort, Alain; and Trognon, Alain. "Pseudo Maximum Likelihood Methods: Application to Poisson Models." Econometrica 52 (1984): 701-20.

Hausman, Jerry; Hall, Bronwyn H.; and Griliches, Zvi. "Econometric Models for Count Data with an Application to the Patents-R\&D Relationship." Econometrica 52 (1984): 909-38.

Lott, John R., Jr. More Guns, Less Crime: Understanding Crime and GunControl Laws. Chicago: University of Chicago Press, 1998.

Lott, John R., Jr. “The Concealed-Handgun Debate.” Journal of Legal Studies 27 (1998): 221-43. 
Lott, John R., Jr., and Mustard, David. B. "Crime, Deterrence, and Rightto-Carry Concealed Handguns.” Journal of Legal Studies 26 (1997): 1-68.

Maddala, G. S. Introduction to Econometrics. 2d ed. New York: Macmillan, 1992.

McCullagh, Peter, and Nelder, John A. Generalized Linear Models. 2d ed. London: Chapman \& Hall, 1989.

Plassmann, Florenz, and Tideman, T. Nicolaus. "A Markov Chain Monte Carlo Analysis of the Effect of Two-Rate Property Taxes on Construction." Journal of Urban Economics 47 (2000): 216-47.

White, Halbert. "Maximum Likelihood Estimation of Misspecified Models." Econometrica 50 (1982): 1-25.

Winkelmann, Rainer, and Zimmermann, Klaus F. "Recent Developments in Count Data Modeling: Theory and Application." Journal of Economic Surveys 9 (1995): 1-24. 